Institute for Research on Poverty

Discussion Paper no. 1016-93

\title{
The Loss of Earnings Capability from Disability/Health Limitations: Toward a New Social Indicator
}

\author{
Robert Haveman \\ Department of Economics \\ La Follette Institute of Public Affairs \\ Institute for Research on Poverty \\ University of Wisconsin-Madison \\ Barbara Wolfe \\ Department of Economics \\ Department of Preventive Medicine \\ Institute for Research on Poverty \\ University of Wisconsin-Madison \\ Lawrence Buron \\ Department of Economics \\ University of Wisconsin-Madison \\ Steven C. Hill \\ Department of Economics \\ University of Wisconsin-Madison
}

August 1993

The authors gratefully acknowledge the assistance of Stephanie Fassnacht and Tom Buchmueller in data preparation. Any opinions expressed are solely those of the authors and not of the sponsoring institutions. 


\begin{abstract}
Health problems and physical and mental impairments can restrict the kind and amount of work that individuals can perform. Several studies have looked at the loss in earnings suffered by disabled/health-limited workers, but they do not examine the trend in this loss over time. The authors propose an alternative indicator of productivity loss that is more appropriate for intertemporal comparisons: "lost earnings capability"--the difference between the amount of money persons could potentially earn if they were free of disability/health limitations and the amount of money that they can actually earn given their limitations. The estimates indicate that the mean lost earnings capability per disabled/health-limited person grew over the period from 1973 to 1988 , while the population with disabilities/health limitations fell. In 1973, lost earnings capacity totaled about 5.3 percent of Gross National Product (GNP); by 1988, the loss had fallen to about 4.5 percent of GNP as a consequence of the reduction in the number of people with limitations. Data are from the Current Population Surveys and the Survey of Income and Program Participation.
\end{abstract}




\section{The Loss of Earnings Capability from Disability/Health Limitations: Toward a New Social Indicator}

\section{INTRODUCTION}

People who are not fully physically or mentally capable of performing a job for which they are otherwise qualified are designated in the literature as disabled or health-limited. ${ }^{1}$ The establishment of disability status for purposes of determining eligibility for public programs is based on reports of medical examinations. ${ }^{2}$ In survey data, determination of the disabled or health-limited population is typically based on self-reported information.

A large number of working-age people in the United States are disabled or have health

problems that limit the amount and type of work they can perform. The size of this population is hard to determine, however, because different definitions of what it means to be health-limited or disabled yield different estimates. Some researchers define a disabled person as a recipient of benefits from one of the major disability income support programs, Social Security Disability Insurance and Supplemental Security Income. In the early 1990s, 6.4 million people--over 4 percent of the population aged 18-64--received benefits from these two programs. Other researchers turn to surveys that ask people if their hours of work are limited by poor health. The Current Population Survey (CPS) indicates that in the late 1980s, over 6 percent of working-age people were unable to work, or were restricted to part-time or part-year work, because of health reasons.

We have estimated the size of the disabled/health-limited population using data from the Current Population Surveys and the Survey of Income and Program Participation (SIPP). According to our CPS-based estimates, 11.1 million people aged eighteen to sixty-four were disabled in 1988. Most of our estimates based on SIPP data are even larger. (We will present a full set of estimates and describe our estimating procedures below.) With so many people restricted in their ability to work by disability/health-limitations, the loss to the nation in terms of potential foregone output is substantial. 
Moreover, disability/health-limitations entail other economic costs as well. Disabled and health-limited individuals require a lot of medical attention, the cost of which is often funded by taxpayers, and they require the time and energy of relatives and other caregivers.

An accurate estimate of the economic loss attributable to disabilities/health-limitations is important to have. When measured over time, such estimates serve to indicate the extent to which the nation's economic growth is depressed or augmented because of changes in disability/health conditions.

Among the studies that have measured the costs to the nation of illness and disability, those of Dorothy Rice and her associates stand out. ${ }^{3}$ In their 1972 estimates of the lost productivity due to ill health, Cooper and Rice (1976) found losses of $\$ 83.4$ billion (1980 dollars), or 6.6 percent of aggregate national wages and salaries, and 3.5 percent of GNP. For the same period, they estimated person-years of work lost to be 5.4 million. In their 1985 study, Rice, Hodgson, and Kopstein estimated the loss of productivity due to these health constraints--characterized as "lost earnings" and lost household services--to be $\$ 67.8$ billion in 1980 , or nearly 3 percent of total national wages and salaries, and 1.7 percent of GNP. Person-years of work lost were estimated to have risen to 6.2 million.

The decline in aggregate value along with an increase in lost work-time is largely unexplained. Disease groups account for similar proportions of the losses in both years. Thus there is need for an examination of intertemporal changes in the economic losses due to disability with a fully consistent methodology. ${ }^{4}$

In this study, we propose a different indicator of the productivity-related losses associated with disability/health limitations. While the measure suggested by Rice et al. concerns the loss of actual earnings due to illness and disability, ours measures the loss of earnings capabilities attributable to 
these limitations. Because the Rice et al. indicator measures how individual earnings respond to disability/health limitations, it reflects individual preferences for work versus leisure.

Our indicator measures the capability of a person to earn income both with and without disability/health limitations, and hence purges the measure from dependence on the individual preferences of the nondisabled.

In addition, our indicator captures the effects of a more comprehensive definition of limitations, measures the effects of limitations on both the quantity and price variables that compose earnings, and corrects other empirical weaknesses that plague the Rice et al. estimates. Moreover, we estimate this productivity loss over time, hence allowing the intertemporal comparisons indicated above.

In Section II, we present the concept of productivity loss attributable to disability/health limitations which we empirically estimate, point out important differences between it and the measures offered by Rice et al., and argue the superiority of our measure for intertemporal comparisons.

Section III describes the procedures that we follow in developing our estimates; as we have noted, our estimates rely on far more detailed information on individuals than does other research on this issue. We describe our procedures in general terms in the text, leaving more detailed descriptions to appendices. ${ }^{5}$ Section IV first presents our estimates of the loss in earnings capabilities from 1973 to 1988, using a single definition of the working-age population with limitations. Then, we present estimates of lost earnings capability for several definitions of the population with limitations for a single intermediate year, 1984. Section V concludes.

\section{TWO CONCEPTS OF PRODUCTIVITY LOSS}

In this section, we describe our concept of productivity loss--lost earnings capability--and the lost earnings concept used by Rice et al. Then, we contrast the two concepts and the estimates based 
on them, and review their relevance for intertemporal comparisons of the economic effects of disability/health limitations.

\section{A. The Concept of Lost Earnings Capability (LEC)}

The concept of productivity-related losses that we estimate is designed to capture the reduction in work force productive capability caused by disability/health limitations. We refer to this concept as "lost earnings capability" (LEC) and define it to be the difference between the actual earnings capability of the working-age population (reflecting actual limitations that constrain their capability to work) and the earnings capability of this population assuming that no work-constraining limitations are present. ${ }^{6}$ Hence, LEC is the lost capacity to produce social output due to disability/health limitations.

Consider the two parts of this definition. The actual earnings capability of members of the working-age population $\left(\mathbf{A E C}_{\mathbf{i}}\right.$ ) is measured as the value of the output (or gross earnings) that would be generated if they were to work the maximum number of hours per year permitted by their actual disability/health conditions, at a wage rate that reflects those conditions. Aggregate actual earnings capability (AEC) is the sum of the individual capabilities, or the sum of potential earnings conditional on actual limitations.

$\underline{\text { Potential earnings capability }}\left(\mathbf{P E C}_{\mathbf{i}}\right)$ is measured as the value of the output (or gross earnings) that working-age persons would generate if they worked to their capacity (full-time, full-year), assuming no disability/health limitations. In this case, capacity work is taken to be 2,000 hours per year, and the wage rate is estimated to be that which would be paid the individual (given his/her human capital characteristics) if no limitations were present. Aggregate potential earnings capability (PEC) is the sum of individual potential earnings conditional on the absence of limitations.

Hence,

$$
\begin{aligned}
& \mathbf{L E C}_{\mathbf{i}}=\mathbf{P E C}_{\mathbf{i}}-\mathbf{A E C}_{\mathbf{i}}, \quad \text { or } \\
& \mathbf{L E C}_{\mathbf{i}}=\mathbf{w}_{\mathrm{i}}^{\mathrm{P}} \overline{\mathbf{H}}_{\mathrm{i}}^{\mathrm{P}}-\mathbf{w}_{\mathrm{i}}^{\mathrm{A}} \overline{\mathbf{H}}_{\mathrm{i}}^{\mathrm{A}},
\end{aligned}
$$


where $\mathrm{w}^{\mathrm{P}}$ is the potential wage if healthy, $\overline{\mathrm{H}}^{\mathrm{P}}$ is potential capacity hours if healthy $(2,000$ hours $), \mathrm{w}^{\mathrm{A}}$ is the actual wage at actual levels of disability/health limitations (if any), and $\overline{\mathrm{H}}^{\mathrm{A}}$ is actual capacity hours. We sum $\mathbf{L E C} \mathbf{C}_{\mathbf{i}}$ over the set of working-age persons defined to have limitations to obtain aggregate lost earnings capability, LEC.

\section{B. The Concept of Lost Earnings (LE)}

In contrast, the value of lost productivity attributable to illness and disability estimated by Rice et al. is the loss of earnings due to these conditions. Earnings loss is defined as the difference between an individual's estimated earnings in the absence of illness or disability, $\mathrm{PE}_{\mathrm{i}}$, and their actual earnings, $\mathrm{AE}_{\mathrm{i}}$.

$$
\begin{aligned}
\mathbf{L E}_{\mathrm{i}} & =\mathbf{P E}_{\mathrm{i}}-\mathrm{AE}_{\mathrm{i}} \\
& =\mathbf{w}_{\mathrm{i}}^{\mathrm{P}} \mathbf{H}_{\mathrm{i}}^{\mathrm{P}}-\mathbf{w}_{\mathrm{i}}^{\mathrm{A}} \mathbf{H}_{\mathrm{i}}^{\mathrm{A}},
\end{aligned}
$$

where $\mathbf{H}_{\mathbf{i}}^{\mathbf{p}}$ is hours of work if healthy (i.e., with no illness or disability) and $\mathbf{H}_{\mathbf{i}}^{\mathbf{A}}$ is actual hours in the paid labor force.

However, in their estimation procedure, Rice et al. do not, in fact, estimate (3). Their actual procedure is to multiply the total days of work lost (for each of a limited number of age-gender groups) by the mean earnings of the entire population of full-time, full-year workers.

This procedure is equivalent to

$$
\mathbf{L E}_{\mathrm{i}}=\mathbf{w}_{\mathrm{i}}^{\mathbf{F}}\left(\mathbf{H}_{\mathrm{i}}^{\mathrm{F}}-\mathbf{H}_{\mathrm{i}}^{\mathrm{A}}\right)
$$

where $\mathbf{w}_{\mathbf{i}}^{\mathbf{F}}$ and $\mathbf{H}^{\mathbf{F}}$ are the wage rate and hours in the paid labor force of full-time, full-year workers, respectively.

Three problems with the procedure described by (4) should be noted. First, the calculation implicitly assumes that illness and disability have no effect on wage rates (i.e., $\mathbf{w}_{\mathbf{i}}^{\mathbf{A}}=\mathbf{w}_{\mathbf{i}}^{\mathbf{F}}$ ). This equality assumption affects their calculation at two points, and at both points the validity of the assumption is questionable. ${ }^{7}$ For individuals who do not work in the paid labor force $\left(\mathbf{H}^{\mathbf{A}}{ }_{\mathbf{i}}=\mathbf{0}\right)$, 
equations (3) and (4) are identical, if one assumes that the wages of individuals without illnesses or disabling conditions are equal to those of full-time, full-year workers $\left(\mathbf{w}_{\mathbf{i}}^{\mathbf{P}}=\mathbf{w}_{\mathbf{i}}^{\mathbf{F}}\right)$. This assumption may or may not be true, and depends on the human capital characteristics and preferences of the two groups. The assumed equality also affects the calculation for people who participate in the paid labor force, and for them the assumption is quite surely wrong. While the wage rates of those with acute conditions are not likely to be adversely affected by their conditions, the wage rates of those with chronic or disabling conditions will be. Such conditions impose direct limitations on labor market opportunities and serve as the basis of discrimination against people with disabilities. ${ }^{8}$ The second problem is a related one. Rice et al. ignore losses due to working part-time owing to disabilities. Only days lost are counted--and they are counted as full-time days lost.

The third problem is even more serious. Rice et al. assume that, in the absence of illness or disabling conditions, all workers would work full-time, full-year. ${ }^{9}$ This assumption is clearly incorrect. Estimates from the CPS show that in 19918.1 percent of the paid labor force works part-time, full-year; 18.4 percent works full-time, part-year, and 10.8 percent work part-time, part-year, and these figures have been increasing over time. Many people work part-time or part-year for reasons other than illness or disability. It should be noted that this full-time, full-year work standard which is the counterfactual for estimating lost productivity, is similar to the standard that we use in the calculation of LEC. However, in Rice et al., the comparison is not consistent. In the measurement of lost earnings, it is not legitimate to compare the actual earnings of those with illnesses and disabling conditions $\left(\mathrm{AE}_{\mathrm{i}}\right)$--which figure includes part-time and part-year work for reasons that are unrelated to health--with this full-time, full-year capacity work standard. ${ }^{10}$ 


\section{C. $\quad$ LEC and LE Compared}

The measure of the "lost earnings" component of the costs of illness developed by Rice et al., and estimated according to equation (4), differs in several ways from our measure of lost earnings capability (LEC), as described in equation (2).

First, whereas Rice et al. take the loss in earnings attributable to illness to be the principal indicator of concern, we focus on the loss in the capability to earn. Each of these concepts has meaning and relevance; they are similar to the concepts of "industrial output" and "potential output of industrial capacity" in appraising the utilization and the level of a stock of physical capital. In much the same way that one stochastic phenomenon (say, a hurricane) reduces the flow of output and the capability of the stock of productive physical capital to produce output, another stochastic phenomenon (say, disability/health limitations) reduces both the flow of earnings and the potential earnings flow from the stock of human capital. Preference for one or another of these concepts depends upon the question one wishes to answer.

Our measure, we would emphasize, is appropriate for making intertemporal comparisons of the effects of changes in health-related conditions, while that of Rice et al. is not. Their measure confounds the productivity effects of changes in health status with the effects of changes in preferences involving paid market work and changes in work incentives.

An example will make this clear. Consider the effects on the two measures of the rapid increase in the work effort of women (thought of as an increase over time in $\mathrm{H}^{\mathrm{P}}$ ). If this increasing supply of female labor is associated with the displacement of women with disabilities from the paid labor force, the estimate of lost earnings (LE) would also increase over time. Because our measure of LEC abstracts induced labor market effects from changed preferences of the nondisabled, its pattern over time would not reflect the change in such preferences. ${ }^{11}$ Our estimates remove these effects from $\overline{\mathbf{H}}^{\mathbf{P}}$, not $\overline{\mathbf{H}}_{\mathrm{A}}$. 
The use of LEC, then, which standardizes the hours component of earnings capability for nondisabled individuals $\left(\overline{\mathrm{H}}^{\mathrm{P}}\right)$ to 2,000 hours in all years, removes the effects of changing preferences and incentives regarding the decision to enter the paid work force from the calculation of the economic loss attributable to changes in disability/health limitations. ${ }^{12}$ LEC, in sum, provides an estimate of the effects of changes in the underlying prevalence of disability/health limitations free of these confounding effects. ${ }^{13}$

A second difference between the Rice et al. indicator and LEC concerns the phenomenon whose effect is being measured. While Rice et al. measure the earnings losses associated with days of work lost due to "illness," we measure the potential productive capability lost due to "disability/health limitations." This, again, is a matter of the question to which an answer is sought. While Rice et al. have evaluated the effects of a variety of particular diseases or disease categories, our estimates are of the productivity losses attributable to a comprehensive set of disability/health limitations.

The third difference is perhaps the most important. For those who are in the labor force, Rice et al. measure the loss in the quantity of work (days of work) attributable to illness, and then value this quantity change by the daily earnings of all full-time, full-year workers. ${ }^{14}$ Our measure accounts for the effect of limitations on both the change in the quantity of work potential and the value of the potential work-time (the wage rate). In short, while our measure reflects the impact of health-related limitations on both the price and quantity variables, the Rice et al. measure captures only the effect of limitations on the quantity variable.

A further distinguishing characteristic of our empirical estimates is their use of very detailed information on individuals. As a result, we provide more accurate estimates of potential earnings than is possible by using comparison groups that only crudely resemble groups of persons with limitations. For example, Rice et al. assume that the actual earnings of health-impaired people are equal to the average earnings of full-time, full-year employed individuals in the same age-gender category. ${ }^{15}$ To 
the extent that we employ more detail--including information on a variety of human capital, location, and demographic characteristics--our estimates will have smaller prediction errors than those using cruder comparisons. ${ }^{16}$

One final difference is in the adjustments made for unemployment by the two measures. Rice et al. multiply LE for each age-gender group by the percentage of the group with positive earnings; this is consistent with a measure of lost earnings. We multiply our measure of LEC by age-gendereducation-specific unemployment rates. This is a consistent adjustment for the macroeconomic limitations on the ability of individuals to utilize their human capital (earnings capability), as opposed to labor supply decisions reflected in earnings. Neither we nor Rice et al. consider the macroeconomic effects of increases in the size of the work force.

\section{ESTIMATING LOST EARNINGS CAPABILITY: EMPIRICAL PROCEDURES}

To calculate lost earnings capability for each individual identified as limited because of disability/health reasons $\left(\mathrm{LEC}_{\mathrm{i}}\right)$, two numbers are required-- $\mathrm{AEC}_{\mathrm{i}}$ and $\mathrm{PEC}_{\mathrm{i}}$. Here, we briefly describe the empirical procedures followed in estimating these values; more detailed discussions are found in Appendix I and Appendix II.

\section{A. $\quad$ Estimates of LEC for 1973 and 1988, Using CPS Data}

Our estimate of $\mathrm{AEC}_{\mathrm{i}}$ and $\mathrm{PEC}_{\mathrm{i}}$ using the CPS data rests on an estimated earnings function fit separately over four gender-race subgroups, for each of the two years. The dependent variable in this equation is the observed level of earnings (in logarithmic form) of the individuals in the sample. The independent variables include a rich set of human capital and demographic characteristics (such as age, education, location, and family status), hours worked in the year, indicators of disability/health status, and an estimated selectivity correction term. ${ }^{17}$ 
These estimated functions are then used to obtain an unbiased prediction of the earnings of an individual of a particular gender and race with a fully specified set of human capital, demographic, hours worked, and health characteristics. ${ }^{18}$ The value of predicted earnings for an individual with a specified set of human capital and demographic characteristics will vary with stipulated values of the health status and hours worked variables.

Given the estimated earnings functions, consider each of the two component numbers:

- $\quad \mathrm{PEC}_{\mathrm{i}}$ is the amount that individuals with limitations could earn, if they were free of the reported disability or health conditions. With the relaxation of the effect of the limitation on both the wage rate and hours worked, the predicted earnings of individuals are obtained by setting the health status variables in the relevant gender-race earnings equations at levels indicating no limitations, and the hours worked variable at 2,000 hours. This prediction uses the estimated coefficients from the relevant earnings equations together with the actual values of the individual's demographic and human capital characteristics. ${ }^{19}$

- $\quad \mathrm{AEC}_{\mathrm{i}}$ is the amount that persons with limitations could earn if they worked at the maximum level permitted by their conditions, and at a wage rate that reflects these conditions. We calculate this amount from the estimated earnings equation in the following steps:

a. For each person with limitations, we predict annual earnings from the relevant gender-race earnings equation, setting the health status variables at their actual levels and the hours worked variable at 2,000 hours. This yields the predicted earnings of these individuals if they could work full-time, full-year, given the nature of their health-limiting conditions. ${ }^{20}$

b. Because individuals with disability/health limitations are constrained from working 2,000 hours, we adjust the annual earnings value predicted in a. downward using information in the survey regarding restrictions on individual work-time. The survey information used to adjust the predicted earnings level includes the individual's weeks unable to work because of limitations and the extent to which these limitations cause part-time rather than full-time work.

This adjusted value, then, is our estimate of the predicted earnings of the person with disability/health limitations reflecting the effect of the limitations on both the implicit wage rate (from a.) and the potential hours worked (from b.).

For each individual classified as disabled/health-limited, the difference between $\mathrm{PEC}_{\mathrm{i}}$ and $\mathrm{AEC}_{\mathrm{i}}$ is our estimate of the earnings potential which is lost because of the limitations--LEC . The aggregate value of lost potential earnings (LEC) is the sum of $\mathrm{LEC}_{\mathrm{i}}$ over all individuals with limitations. 
B. Estimates of LEC for 1984, Using SIPP Data

In estimating $\mathrm{PEC}_{\mathrm{i}}$ and $\mathrm{AEC}_{\mathrm{i}}$ for 1984, we estimate both an hours worked and a wage rate equation (both in logarithmic form) over males and females in the SIPP data. The independent variables in the hours equation are designed to measure alternative time demands, labor market conditions, human capital, other personal characteristics, exogenous incentives to work, and variables reflecting disability/health limitations. This equation is estimated as a tobit specification, designed to take into account the fact that a number of individuals do not participate in the paid labor force. Independent variables in the wage rate equation include a rich set of human capital and demographic characteristics, labor market conditions, and the same disability/health limitation variables as included in the hours equation. This equation also includes a selection control variable obtained from the hours equation. $^{21}$

Again, these estimated functions are used to obtain an unbiased prediction of the earnings of individuals with a fully specified set of human capital and demographic characteristics, both with and without the presence of disability/health limitations.

Consider the definitions of $\mathrm{PEC}_{\mathrm{i}}$ and $\mathrm{AEC}_{\mathrm{i}}$ :

- Again, $\mathrm{PEC}_{\mathrm{i}}$ is the amount that individuals with limitations could earn if they were free of the reported disability or health conditions. The predicted value of $\mathrm{PEC}_{\mathrm{i}}$ is the product of the predicted wage rate (setting the health variables at levels indicating no disability/health limitation) and 2,000 hours of work. The coefficient on the selectivity variable is not employed in the prediction. ${ }^{22}$

- $\quad \mathrm{AEC}_{\mathrm{i}}$ is again the amount that persons with limitations could earn if they worked at the maximum level permitted by their conditions, and at a wage rate that reflects these conditions. $\mathrm{AEC}_{\mathrm{i}}$ is obtained by adjusting both the wage rate and hours worked for the presence of disability/health limitations. Predicted wages are estimated by using the coefficients from the wage equation, including those on reported disability or health. This predicted wage is then multiplied by an estimate of the number of hours that the individual could work, given the nature of their health-limiting conditions. ${ }^{23}$

$\mathrm{LEC}_{\mathrm{i}}$ is estimated by subtracting actual earnings capability $\left(\mathrm{AEC}_{\mathrm{i}}\right)$ from potential earnings capability $\left(\mathrm{PEC}_{\mathrm{i}}\right)$. 


\section{ESTIMATES OF LOST EARNINGS CAPABILITY: 1973-1988}

\section{A. Estimates of the Disabled/Health-Limited Working Age Population}

The first step in estimating lost potential earnings is to identify the working-age population who are disabled/health-limited; it is this population that loses potential earnings. As suggested in Section I, identifying the population with limitations is problematic and requires establishing a standard that is both judgmental and operational. Obviously, different definitions will yield varying rates of disability prevalence, which in turn affect estimates of LEC.

We identify the working-age, disabled/health-limited population using three approaches: for the CPS, (1) a self-reported work limitation and program participation measure (see Wolfe and Haveman, 1990); for the SIPP, (2) self-reported health status and (3) functional disability. We chose these approaches largely on grounds of empirical tractability--each uses information from household surveys that also contain sufficient demographic, labor force, and income information to estimate LEC for the nation's working-age population over time.

Although the health/disability information available from the CPS is less detailed than that from other data sets, the rich demographic and labor force information and its availability over many years led us to rely on it for our intertemporal estimates.

The more detailed health data in the third wave of the 1984 Panel of the SIPP ${ }^{24}$ are used to examine the robustness of our CPS-based estimates of LEC, and to permit LEC estimates at a point in time based on a range of definitions--representing a range of norms--of the health-limited population. Using both data sets, then, we can examine the changes in LEC over time and the sensitivity of LEC to a range of definitions of the disabled/health-limited population.

In working with the CPS, we identify the population with limitations from responses to questions regarding the reasons for not working full-time, full-year and the sources of income. Our 
definition is based on (1) reported limitations in the time an individual works (work activity last year; working part-year or part-time hours last year) and (2) the receipt of transfer income from programs for people with severe and long-term limitations (Social Security Disability Insurance, Supplemental Security Income, Veterans benefits for disabled persons, and Workers' Compensation). ${ }^{25}$

Two weaknesses of our CPS definition of the population with limitations should be noted. First, the work-limited category is composed of people who self-report being unable to work full-time, full-year because of limitations. For some respondents, claiming limitations may be endogenous to a decision to not work made for other reasons. Second, our program participation measure assumes that the eligibility criteria for receipt of disability benefits were the same in both 1973 and 1988 . To the extent that the stringency of these criteria differs between the years, our estimates of the population with limitations--and aggregate LEC--will reflect these differences.

Table 1 presents our CPS-based estimates of the working-age population with limitations for both 1973 and 1988. We classify 9.8 percent of the working-age population (ages 18-64) as having disabilities/health-limitations in 1973, and 7.6 percent in 1988. The prevalence of persons with disabilities has been consistently greater among working-age men than among women, but the pattern of decreasing prevalence since 1973 is consistent across genders. The number of persons with limitations in our CPS estimates is smaller than those calculated using other data sets, and the reduction in the prevalence of such persons over time is somewhat more pronounced. ${ }^{26}$

We employ data from SIPP to present four alternative estimates of the working-age population with disability/health limitations. These results are presented in Table 2. A commonly used measure of health status is self-reported health on a five-point scale of poor to excellent; we identify the population with limitations as those who self-report poor or fair health. We find those with fair or 
TABLE 1

Number and Percentage of Working-Age Persons Classified as Disabled: 1973 and 1988

\begin{tabular}{|c|c|c|c|c|}
\hline & \multicolumn{2}{|c|}{1973} & \multicolumn{2}{|c|}{1988} \\
\hline & $\begin{array}{l}\text { Number (in } \\
\text { Millions) }\end{array}$ & $\begin{array}{c}\% \text { of Population } \\
\text { Group }\end{array}$ & $\begin{array}{l}\text { Number (in } \\
\text { Millions) }\end{array}$ & $\begin{array}{c}\% \text { of Population } \\
\text { Group }\end{array}$ \\
\hline Total & 11.2 & 9.8 & 11.1 & 7.6 \\
\hline \multicolumn{5}{|l|}{ Ages } \\
\hline $18-24$ & 1.4 & 5.6 & 1.0 & 4.0 \\
\hline $25-34$ & 2.1 & 7.4 & 2.2 & 5.2 \\
\hline $35-44$ & 1.8 & 8.2 & 2.5 & 7.1 \\
\hline $45-54$ & 2.9 & 12.7 & 2.3 & 9.7 \\
\hline $55-64$ & 3.0 & 18.0 & 3.0 & 15.9 \\
\hline \multicolumn{5}{|l|}{ Gender } \\
\hline Male & 6.4 & 11.4 & 5.9 & 8.3 \\
\hline Female & 4.8 & 8.2 & 5.2 & 7.1 \\
\hline \multicolumn{5}{|l|}{ Race } \\
\hline White & 8.7 & 8.9 & 8.2 & 7.0 \\
\hline Black & 1.9 & 16.3 & 1.9 & 11.5 \\
\hline Hispanic & 0.6 & 11.2 & 0.8 & 6.8 \\
\hline
\end{tabular}

Source: Authors' calculations from the March 1974 and 1989 Current Population Surveys. 
TABLE 2

Number and Percentage of Working-Age Persons with Health Problems/Disabilities, 1984, Various Definitions

\begin{tabular}{|c|c|c|c|c|c|c|c|c|}
\hline & \multicolumn{2}{|c|}{$\begin{array}{l}\text { Poor or Fair Health } \\
\text { or with } 1+\text { ADL } \\
\text { Limitations }\end{array}$} & \multicolumn{2}{|c|}{$\begin{array}{r}\text { With 1+ ADL } \\
\text { Limitations }\end{array}$} & \multicolumn{2}{|c|}{ Poor or Fair Health } & \multicolumn{2}{|c|}{$\begin{array}{c}\text { With } 2+\text { ADL } \\
\text { Limitations }\end{array}$} \\
\hline & $\begin{array}{l}\text { Number (in } \\
\text { Millions) }\end{array}$ & $\begin{array}{l}\% \text { of Pop. } \\
\text { Group }\end{array}$ & $\begin{array}{l}\text { Number (in } \\
\text { Millions) }\end{array}$ & $\begin{array}{l}\% \text { of Pop. } \\
\text { Group }\end{array}$ & $\begin{array}{l}\text { Number (in } \\
\text { Millions) }\end{array}$ & $\begin{array}{l}\% \text { of Pop. } \\
\text { Group }\end{array}$ & $\begin{array}{l}\text { Number (in } \\
\text { Millions) }\end{array}$ & $\begin{array}{l}\% \text { of Pop. } \\
\text { Group }\end{array}$ \\
\hline Total & 24.0 & 19.6 & 18.2 & 14.9 & 14.4 & 11.8 & 8.5 & 6.9 \\
\hline \multicolumn{9}{|l|}{ Age } \\
\hline $19-24$ & 1.6 & 9.6 & 1.0 & 6.0 & .9 & 5.3 & .3 & 2.5 \\
\hline $25-34$ & 4.0 & 10.8 & 2.8 & 7.6 & 2.1 & 5.6 & .9 & 2.5 \\
\hline $35-44$ & 5.0 & 17.2 & 3.7 & 12.9 & 2.6 & 9.1 & 1.5 & 5.1 \\
\hline $45-54$ & 5.9 & 28.6 & 4.7 & 22.6 & 3.6 & 17.6 & 2.2 & 10.8 \\
\hline $55-64$ & 7.4 & 41.0 & 6.0 & 33.0 & 5.2 & 28.6 & 3.5 & 19.5 \\
\hline \multicolumn{9}{|l|}{ Gender } \\
\hline Male & 11.0 & 18.3 & 8.2 & 13.7 & 6.6 & 10.9 & 3.5 & 5.8 \\
\hline Female & 13.0 & 20.9 & 10.0 & 16.1 & 7.9 & 12.7 & 5.0 & 8.0 \\
\hline \multicolumn{9}{|l|}{ Race } \\
\hline White & 18.6 & 18.0 & 14.4 & 14.0 & 10.6 & 10.3 & 6.4 & 6.2 \\
\hline Black & 4.1 & 30.4 & 2.9 & 21.3 & 2.9 & 21.9 & 1.5 & 11.3 \\
\hline Hispanic & 1.3 & 23.1 & 1.0 & 16.8 & .9 & 15.8 & .5 & 8.9 \\
\hline
\end{tabular}

Source: Authors' calculations from SIPP, 1984 Panel. 
poor health are 11.8 percent of the population, 10.9 percent of men and 12.7 percent of women. Table 2 also reports the prevalence of persons with functional disabilities, measured as performing with difficulty one or more--and two or more--work-related Activities of Daily Living (ADLs). ${ }^{27}$ Finally, we define anyone who meets either of these definitions as disabled/health-limited.

The prevalence of persons with limitations across these four definitions ranged from 6.9 percent to 19.6 percent of the working-age population in 1984 . The variation in prevalence rates across these definitions, each of which has a legitimate basis, highlights the difficulty in clearly defining the population with limitations using any existing data set.

\section{B. Estimates of Aggregate Lost Earnings Capability}

Our CPS-based estimates of aggregate LEC for the U.S. economy are presented in the first two columns of Table 3. We estimate that aggregate LEC was $\$ 131.3$ billion in 1973 and $\$ 128.4$ billion in 1988. ${ }^{28}$ From this, we conclude that disabilities/health-limitations reduced aggregate earnings capabilities in the United States by about 5.3 percent in 1973 and 4.5 percent in 1988 . The average (mean) loss of earnings capabilities per person with limitations remained virtually the same over this period; it was \$11,700 in 1973 and \$11,600 in 1988 .

Two offsetting factors account for the constancy of aggregate LEC over the 1973 to 1988 period. Although the total number of working-age (ages 20-64) people in the nation rose from 108 million to 145 million over the 1973-1988 period (an increase of 34 percent), the proportion of them with limitations actually fell (see Table 1).

The second bank of four columns in Table 3 shows estimates of LEC in 1984, obtained by applying our estimation procedures to the working-age population with limitations in SIPP. Although SIPP is unable to provide evidence of the trend in lost productivity due to limitations, it contains detailed information on limitations that enable us to examine the value of LEC using a range of 
TABLE 3

Aggregate Loss of Earnings Capability (LEC) Due to

Health Problems/ Disabilities: 1973, 1984, and 1988

(In 1988 dollars)

\begin{tabular}{|c|c|c|c|c|c|c|}
\hline & \multirow[b]{2}{*}{1973} & \multirow[b]{2}{*}{1988} & \multicolumn{4}{|c|}{1984} \\
\hline & & & $\begin{array}{c}\text { Poor or Fair } \\
\text { Health or with } \\
1+\text { ADL Limitation }\end{array}$ & $\begin{array}{l}\text { With } 1+ \\
\text { ADL } \\
\text { Limitation }\end{array}$ & $\begin{array}{l}\text { Poor or } \\
\text { Fair } \\
\text { Health }\end{array}$ & $\begin{array}{l}\text { With } 2+ \\
\text { ADL } \\
\text { Limitation }\end{array}$ \\
\hline Percentage of population & 11.2 & 11.1 & 19.6 & 18.2 & 14.4 & 6.9 \\
\hline $\begin{array}{l}\text { Aggregate lost } \\
\text { earnings capacity } \\
\text { (in billions of dollars) }\end{array}$ & $\$ 131.3$ & $\$ 128.4$ & $\$ 284.5$ & $\$ 227.4$ & $\$ 191.9$ & $\$ 130.8$ \\
\hline $\begin{array}{l}\text { LEC as a percentage of } \\
\text { the entire working-age } \\
\text { population's EC }\end{array}$ & $5.3 \%$ & $4.5 \%$ & $10.6 \%$ & $8.5 \%$ & $7.2 \%$ & 4.9 \\
\hline $\begin{array}{l}\text { LEC per person with health } \\
\text { problems/disability } \\
\text { (in thousands of dollars) }\end{array}$ & $\$ 11.7$ & $\$ 11.6$ & $\$ 11.9$ & $\$ 12.5$ & $\$ 13.3$ & $\$ 15.5$ \\
\hline
\end{tabular}

Source: Authors' calculations from March 1974 and 1989 CPS, and SIPP, 1984 panel. 
definitions of the population with limitations. Table 3 presents four LEC estimates, each based on a somewhat different definition of the population with limitations.

The largest estimate of LEC--\$284.5 billion, or 10.6 percent of the total earnings capabilities of the nation's working-age population in the absence of limitations--is for the 19.6 percent of this population who either reported poor or fair health on the five-point health scale or who reported one or more limitations in Activities of Daily Living (ADLs). This value is substantially larger than that estimated from the CPS data, and the reason for this difference is clear. The definition of the population of persons with limitations on which the SIPP estimate is based--anyone with a health compromise on either criterion--is far more inclusive than that used in the CPS calculations. More than twice the proportion of the working-age population were disabled/health-limited according to this SIPP definition (19.6 percent) than according to the CPS definition (9.8 percent in 1973; 7.6 percent in 1988).

The smallest SIPP estimate of LEC in Table 3 is for the 6.9 percent of the working-age population who reported limitations in two or more ADLs. This population, which included only those with quite severe limitations, yielded a very high average LEC of $\$ 15,500$ and an aggregate LEC of $\$ 130.8$ billion. This SIPP population comes the closest in size to the population of persons with disabilities defined in the CPS--6.9 percent versus 7.6 percent in 1988--and has an estimated LEC which is very close to that in the CPS--4.9 percent of estimated aggregate healthy earnings capacity as compared to the 1988 CPS estimate of 4.5 percent. The remaining estimates based on other definitions of limitations are in between these. 


\section{Estimates of Lost Earnings Capability for Specific Groups}

Tables 4 and 5 present details of our CPS and SIPP estimates of LEC, breaking down the calculations into age, race, gender, and education groups.

The results for the CPS calculations (Table 4) show that LEC per working-age person fell over the fifteen-year period from $\$ 1,100$ to $\$ 900$. This reflects both the small decrease in aggregate LEC and the increase in the size of the working-age population.

Our results on the composition of LEC indicate that mean levels generally increase with age. In 1988, those aged 18-24 who were disabled/health-limited had a mean LEC of \$6,200 (implying a 48 percent loss of potential earnings capability [PEC]); those aged 25-34 had a mean loss of \$8,600 (or 51 percent); those aged 55-64 had a mean loss equal to $\$ 15,200$ (or 78 percent). These percentage losses were greater in 1988 than in 1973 for all age categories except the youngest.

The value of LEC by gender indicates a greater total and mean LEC for men than for women with such limitations. This pattern is expected, and reflects the greater labor market experience and wage rates of men. The pattern is more complex than this observation, however; LEC as a percentage of potential earnings capability (PEC) is substantially greater for the average woman with limitations than for the average man. In 1973, for example, the mean LEC for women was $\$ 9,100$, implying a 67 percent loss of potential earnings. For men with limitations, mean LEC was \$13,600, implying a 48 percent loss of potential earnings capability. While the typical woman with limitations lost about twothirds of her potential earnings capability because of the conditions, the typical male lost only about 50

percent. By 1988, the proportional loss of potential earnings across males and females with limitations had substantially converged--it stood at about 60 percent for men and 66 percent for women. ${ }^{29}$ The relative loss to men with health limitations had clearly increased over this period.

The racial differences in average LEC as a proportion of potential earnings capability ranged from 66 percent for blacks with limitations to 51 percent for whites in 1973, and from 72 percent for 
blacks to 61 percent for whites in 1988. However, the absolute mean loss for whites was substantially larger than that for blacks.

The mean loss in potential earnings capability was greater for limited persons with more human capital, as measured by level of education. This was true in both 1973 and 1988, but the difference had grown over time. This pattern is consistent with the growing differential in earnings by education over this period across the entire population.

Lost earnings capabilities (LEC) per person with limitations was very large. Moreover, this average loss as a proportion of their potential earnings capability increased over time--from about 53 to 62 percent. For men, in particular, the ability of those with limitations to productively use their earnings capabilities declined from the early 1970s to the late 1980s. However, because LEC per disabled/health-limited person remained constant at about $\$ 11,700$, this increase in loss as a percentage of potential earnings capability (PEC) was primarily attributable to the reduction in the estimated PEC of the disabled population from $\$ 22,113$ to $\$ 18,660$ (not shown in the tables). This reduction reflects the general deterioration of real earnings in the U.S. economy over this period, along with an erosion of the underlying human capital and changes in demographic characteristics (e.g., education, age) that determine earnings potential. Hence, the decline in aggregate LEC from $\$ 131.3$ billion to $\$ 128.4$ billion was due primarily to the decline over time in the number of individuals with limitations.

The 1984 results based on the SIPP (Table 5) confirm the robustness of the patterns of lost potential earnings observed in Table 4. For each of the four definitions of the population with limitations, mean LEC rises with age and education, and is greater for males than for females and for whites than for blacks and Hispanics. The patterns of LEC as a percentage of potential earnings 
TABLE 4

Loss of Earnings Capability (LEC) Due to Health Problems/Disability, 1973 and 1988 (in 1988 Dollars)

\begin{tabular}{|c|c|c|c|c|c|c|}
\hline & \multicolumn{3}{|c|}{1973} & \multicolumn{3}{|c|}{1988} \\
\hline & $\begin{array}{c}\text { Mean } \\
\text { LEC } \\
\text { (\$ thousands) }\end{array}$ & $\begin{array}{c}\text { LEC as } \\
\% \\
\text { PEC }\end{array}$ & $\begin{array}{l}\text { Aggregate } \\
\text { LEC } \\
\text { (\$ billions) }\end{array}$ & $\begin{array}{c}\text { Mean } \\
\text { LEC } \\
\text { (\$ thousands) }\end{array}$ & $\begin{array}{c}\text { LEC as } \\
\% \\
\text { PEC }\end{array}$ & $\begin{array}{l}\text { Aggregate } \\
\text { LEC } \\
\text { (\$ billions) }\end{array}$ \\
\hline Total population & 1.1 & 5.3 & 131.3 & .9 & 4.5 & 128.4 \\
\hline $\begin{array}{l}\text { Population with } \\
\text { disabilities }\end{array}$ & 11.7 & 52.9 & 131.3 & 11.6 & 62.3 & 128.4 \\
\hline \multicolumn{7}{|l|}{ Age } \\
\hline $18-24$ & 9.0 & 54.7 & 12.2 & 6.2 & 48.3 & 6.5 \\
\hline $25-34$ & 9.4 & 41.5 & 20.4 & 8.6 & 51.3 & 19.4 \\
\hline $35-44$ & 10.7 & 46.2 & 19.0 & 11.3 & 54.1 & 28.1 \\
\hline $45-54$ & 12.8 & 51.8 & 37.1 & 12.8 & 64.6 & 29.5 \\
\hline $55-64$ & 14.1 & 66.5 & 42.6 & 15.2 & 78.3 & 45.0 \\
\hline \multicolumn{7}{|l|}{ Gender } \\
\hline Male & 13.6 & 47.5 & 87.7 & 14.2 & 60.4 & 83.4 \\
\hline Female & 9.1 & 66.6 & 43.6 & 8.7 & 66.0 & 45.0 \\
\hline \multicolumn{7}{|l|}{ Race } \\
\hline White & 12.3 & 50.9 & 107.0 & 12.4 & 60.7 & 101.8 \\
\hline Black & 9.7 & 66.2 & 18.6 & 9.8 & 72.4 & 18.7 \\
\hline Hispanic & 9.8 & 58.1 & 5.6 & 8.6 & 62.2 & 7.9 \\
\hline \multicolumn{7}{|l|}{ Education } \\
\hline $0-11$ & 11.0 & 62.9 & 60.8 & 10.1 & 76.9 & 42.6 \\
\hline 12 & 11.6 & 49.6 & 41.7 & 11.4 & 59.6 & 48.8 \\
\hline $13-15$ & 12.5 & 45.0 & 17.0 & 12.5 & 54.0 & 20.1 \\
\hline $16+$ & 15.6 & 39.8 & 11.8 & 18.3 & 54.0 & 17.0 \\
\hline
\end{tabular}

Source: Authors' calculations from March 1974 and 1989 CPS. 
TABLE 5

Loss of Earnings Capability (LEC) Due to Health Problems/Disability,

1984, Various Definitions of Persons with Disabilities (in 1988 Dollars)

\begin{tabular}{|c|c|c|c|c|c|c|c|c|c|c|c|c|}
\hline & \multicolumn{3}{|c|}{$\begin{array}{l}\text { Poor or Fair Health or with } \\
1+\text { ADL Limitations }\end{array}$} & \multicolumn{3}{|c|}{ With 1+ ADL Limitations } & \multicolumn{3}{|c|}{ Poor or Fair Health } & \multicolumn{3}{|c|}{ With 2+ ADL Limitations } \\
\hline & $\begin{array}{l}\text { Mean } \\
\text { LEC } \\
\text { (\$ thousands) }\end{array}$ & $\begin{array}{c}\text { LEC as } \\
\% \\
\text { PEC }\end{array}$ & $\begin{array}{l}\text { Aggregate } \\
\text { LEC } \\
\text { ( } \$ \text { billions) }\end{array}$ & $\begin{array}{c}\text { Mean } \\
\text { LEC } \\
\text { (\$thousands) }\end{array}$ & $\begin{array}{c}\text { LEC as } \\
\% \\
\text { PEC }\end{array}$ & $\begin{array}{l}\text { Aggregate } \\
\text { LEC } \\
\text { ( } \$ \text { billions) }\end{array}$ & $\begin{array}{c}\text { Mean } \\
\text { LEC } \\
\text { (\$ thousands) }\end{array}$ & $\begin{array}{c}\text { LEC as } \\
\% \\
\text { PEC }\end{array}$ & $\begin{array}{l}\text { Aggregate } \\
\text { LEC } \\
\text { ( } \$ \text { billions) }\end{array}$ & $\begin{array}{c}\text { Mean } \\
\text { LEC } \\
\text { (\$ thousands) }\end{array}$ & $\begin{array}{c}\text { LEC as } \\
\% \\
\text { PEC }\end{array}$ & $\begin{array}{l}\text { Aggregate } \\
\text { LEC } \\
\text { ( } \$ \text { billions) }\end{array}$ \\
\hline Total population & 2.3 & 10.6 & 284.5 & 1.9 & 8.5 & 227.4 & 1.6 & 7.2 & 191.9 & .8 & 4.9 & 130.8 \\
\hline $\begin{array}{l}\text { Population with } \\
\text { disabilities }\end{array}$ & 11.9 & 59.4 & 284.5 & 12.5 & 61.9 & 227.4 & 13.3 & 69.4 & 191.9 & 15.5 & 81.8 & 130.8 \\
\hline Age & & & & & & & & & & & & \\
\hline 19-24 & 6.9 & 52.1 & 11.3 & 7.0 & 52.9 & 7.1 & 7.7 & 58.9 & 6.9 & 9.4 & 76.9 & 2.9 \\
\hline $25-34$ & 9.1 & 53.6 & 36.6 & 9.5 & 54.6 & 26.9 & 9.9 & 62.9 & 20.8 & 12.7 & 78.5 & 11.8 \\
\hline $35-44$ & 11.2 & 55.4 & 56.0 & 11.7 & 56.7 & 44.0 & 12.3 & 66.4 & 32.5 & 15.3 & 78.9 & 22.5 \\
\hline $45-54$ & 12.9 & 59.8 & 76.3 & 13.4 & 62.1 & 62.5 & 14.2 & 70.5 & 51.6 & 15.8 & 82.6 & 35.3 \\
\hline $55-64$ & 14.1 & 65.1 & 104.2 & 14.5 & 68.6 & 86.9 & 15.5 & 73.2 & 80.1 & 16.6 & 83.4 & 58.4 \\
\hline Gender & & & & & & & & & & & & \\
\hline Male & 14.9 & 58.2 & 163.7 & 15.5 & 59.8 & 127.9 & 17.3 & 69.5 & 113.2 & 20.4 & 81.4 & 70.6 \\
\hline Female & 9.3 & 61.2 & 120.7 & 9.9 & 64.7 & 99.5 & 10.0 & 69.2 & 78.7 & 12.1 & 82.3 & 60.2 \\
\hline
\end{tabular}


TABLE 5 (continued)

\begin{tabular}{|c|c|c|c|c|c|c|c|c|c|c|c|c|}
\hline & \multicolumn{3}{|c|}{$\begin{array}{l}\text { Poor or Fair Health or with } \\
1+\text { ADL Limitations }\end{array}$} & \multicolumn{3}{|c|}{ With $1+$ ADL Limitations } & \multicolumn{3}{|c|}{ Poor or Fair Health } & \multicolumn{3}{|c|}{ With 2+ ADL Limitations } \\
\hline & $\begin{array}{l}\text { Mean } \\
\text { LEC } \\
\text { (\$ thousands) }\end{array}$ & $\begin{array}{c}\text { LEC as } \\
\% \\
\text { PEC }\end{array}$ & $\begin{array}{l}\text { Aggregate } \\
\text { LEC } \\
\text { ( } \$ \text { billions) }\end{array}$ & $\begin{array}{c}\text { Mean } \\
\text { LEC } \\
\text { (\$ thousands) }\end{array}$ & $\begin{array}{c}\text { LEC as } \\
\% \\
\text { PEC }\end{array}$ & $\begin{array}{l}\text { Aggregate } \\
\text { LEC } \\
\text { ( } \$ \text { billions) }\end{array}$ & $\begin{array}{c}\text { Mean } \\
\text { LEC } \\
\text { (\$thousands) }\end{array}$ & $\begin{array}{c}\text { LEC as } \\
\% \\
\text { PEC }\end{array}$ & $\begin{array}{l}\text { Aggregate } \\
\text { LEC } \\
\text { ( } \$ \text { billions) }\end{array}$ & $\begin{array}{l}\text { Mean } \\
\text { LEC } \\
\text { (\$ thousands) }\end{array}$ & $\begin{array}{c}\text { LEC as } \\
\% \\
\text { PEC }\end{array}$ & $\begin{array}{l}\text { Aggregate } \\
\text { LEC } \\
\text { ( } \$ \text { billions) }\end{array}$ \\
\hline \multicolumn{13}{|l|}{ Race } \\
\hline White/Other & 12.8 & 58.7 & 236.9 & 13.3 & 60.8 & 190.9 & 14.7 & 69.5 & 155.2 & 16.7 & 81.4 & 107.6 \\
\hline Black & 8.8 & 63.1 & 35.9 & 9.6 & 68.2 & 27.2 & 9.5 & 69.0 & 28.0 & 11.4 & 83.9 & 17.2 \\
\hline Hispanic & 8.6 & 63.5 & 11.7 & 9.4 & 68.1 & 9.3 & 9.4 & 69.9 & 8.7 & 11.4 & 82.8 & 6.1 \\
\hline \multicolumn{13}{|l|}{ Education } \\
\hline 0-11 & 10.2 & 64.9 & 103.4 & 10.9 & 69.1 & 84.3 & 11.2 & 72.1 & 80.1 & 12.9 & 83.5 & 57.5 \\
\hline 12 & 11.5 & 58.0 & 102.8 & 12.1 & 60.2 & 80.4 & 13.5 & 67.8 & 68.2 & 16.0 & 81.1 & 42.1 \\
\hline $13-15$ & 13.4 & 57.1 & 40.4 & 13.9 & 58.2 & 31.9 & 16.0 & 67.9 & 24.9 & 19.1 & 80.6 & 17.2 \\
\hline $16+$ & 19.6 & 52.9 & 37.8 & 19.7 & 53.3 & 30.8 & 25.9 & 66.9 & 18.7 & 28.9 & 78.6 & 14.1 \\
\hline
\end{tabular}

Source: Authors' calculations from SIPP, 1984 Panel. 
capability are also replicated across the alternative definitions. The proportional losses rise with age, are higher for blacks and Hispanics than for whites, and decrease with years of education.

However, there are two differences between the CPS and SIPP results concerning males and females. First, the estimates of the proportional losses for females are closer to those of males in the SIPP data than in the CPS estimates. Second, in the SIPP estimates a larger proportion of total aggregate LEC is lost by females than in the CPS estimates--about 43 percent versus about 34 percent. These differences are due to the varying information on limitations available in the two data sets and the resulting greater prevalence of limitations among females in the SIPP data. ${ }^{30}$

The pattern of decreasing estimates of aggregate LEC as more restrictive definitions of the population with limitations are used is replicated across age, gender, race, and education groups.

\section{CONCLUSION}

Our estimates of the loss in earnings capabilities and productivity in the mid-1980s attributable to the prevalence of disabilities/healthlimitations in the U.S. working-age population (LEC) range from about \$131 billion annually for a narrowly defined population of persons with limitations (composing about 7 percent of the working-age population) to about $\$ 285$ billion annually for a broadly defined population with limitations (one including nearly 20 percent of the working-age population). These figures imply a loss ranging from about 5 percent to about 10 percent of the potential earnings capability (PEC) of the entire U.S. working-age population. 
For the CPS definition (and for a population of persons with limitations comparable in number to that based on the SIPP definition of those with two or more ADLs), the aggregate loss of earnings capabilities (LEC) was about 4-5 percent of potential labor earnings--and hence productivity--in the mid-1980s. The presence of these limitations cost the average person with limitations about 59 percent of their potential earnings for the broader SIPP definition and about 82 percent for the narrow definition based on limitations in at least two ADLs. For the CPS definition, the percentage loss of potential earnings increased from 53 percent in 1973 to 62 percent in 1988.

We find that lost earnings capabilities due to disability/health limitations (LEC) in this country declined slightly from the early 1970 s to the late $1980 \mathrm{~s}$, from 5.3 to 4.5 percent of the potential earnings capability of the working-age population. We attribute this decrease to the reduction in the number of persons with limitations, rather than a reduction in the lost earnings capabilities of those persons with limitations. This latter value (LEC) remained constant at about $\$ 11,700$. The number of individuals identified in the 1988 CPS as limited lies close to that identified in the SIPP data using the definition based on the presence of two or more ADL limitations. ${ }^{31}$ The SIPP results also provide insight into the link between limitations and the loss in potential earnings. They show a strong positive relationship between the loss of potential earnings capability and the size of the population with limitations. The full definition of limitations that includes all people that report poor or fair health or one or more ADL limitation suggests an upper bound on the loss in potential earnings and productivity due to disability/health conditions.

We would again emphasize that our LEC measure is designed to increase the accuracy of estimates of market-valued productivity loss by measuring the full reduction in potential earnings capabilities due to disability/health limitations. ${ }^{32}$ As a measure of the loss of economic productivity, our LEC estimates take into account far more detail on individuals and reflect a rather different concept of economic loss--loss in 
the value of potential human capital services, rather than the loss in earnings--than others available in the literature. ${ }^{33}$ Our estimates are also available over time, hence allowing for intertemporal comparisons with both the number of individuals classified as disabled/health-limited and the volume of public transfers targeted at this population.

The decline in the calculated loss of earnings capabilities (LEC) is encouraging and suggests that the U.S. economy is, on average, less earnings-constrained by disability/health limitations today than fifteen years ago. However, for those with limitations, the absolute value of mean LEC has not declined. Indeed, relative to their potential earnings capability (PEC), the loss incurred by those with limitations has increased.

As disability transfer rolls grow, one has the tendency to think that either the health status of our country has deteriorated or that the disability transfer programs (Social Security Disability Insurance and Supplementary Security Income) have determined that more persons are eligible. Our LEC estimates offer an alternative view: (1) the proportion of our working-age population with health/disability limitations has not grown, but (2) the LEC per disabled person has grown. This growth in LEC may explain the recent growth in disability transfer recipients: those persons with disabilities are doing worse in the labor market (their LEC as a percentage of PEC was greater in the late 1980s than in the early 1970s). To offset this loss, more persons with disabilities/health problems may be applying for and being declared eligible to receive SSDI/SSI benefits. 


\section{APPENDIX I}

\section{Empirical Procedures for Estimating Lost Potential Earnings From Disability/Health Limitations Using CPS Data}

For each person identified as having a disability/health limitation, the loss in earnings capability due to their disability/health limitation $\left(\mathrm{LEC}_{\mathrm{i}}\right)$ is measured by subtracting actual earnings capability $\left(\mathrm{AEC}_{\mathrm{i}}\right)$ from potential earnings capability $\left(\mathrm{PEC}_{\mathrm{i}}\right)$. That is, for individual $\mathrm{i}$,

$$
\mathrm{LEC}_{\mathrm{i}}=\mathrm{PEC}_{\mathrm{i}}-\mathrm{AEC}_{\mathrm{i}} \text {, }
$$

where $\mathrm{PEC}_{\mathrm{i}}$ is a prediction of person i's earnings if person $\mathrm{i}$ worked full-time, year-round and was free of health limitations. $\mathrm{AEC}_{\mathrm{i}}$ is a prediction of person i's earnings if person i worked the maximum (or capacity) number of hours per year permitted by his/her actual disability/health condition at a wage rate that reflects his/her health condition. Aggregate lost earnings capability (LEC) is simply the sum of each disabled/health-limited individual's LEC $_{\mathrm{i}}$.

We relied on microdata from the March 1974 (for income year 1973) and March 1989 (for income year 1988) CPS surveys for our estimates. Our procedures for estimating $\mathrm{LEC}_{\mathrm{i}}$ in 1973 and 1988 are as follows.

\section{Earnings Functions}

We fit an identical two-equation model for four race-gender (white-nonwhite; male-female) groups using CPS data, for both 1974 and 1989.

The first equation is a reduced-form probit estimation of the determinants of labor force participation designed to generate a selection variable for inclusion in the second-stage earnings equation. The correlates of the labor force participation of working adults of each race- 
gender category are estimated for 1973 and 1988. In the probit estimation, the dependent variable is dichotomous with observations assigned a value of 1 if they have positive log earnings in the year and 0 otherwise. The independent variables include factors that are expected to influence the expected market wage (e.g., education and age), the incentive to work (e.g., nonlabor income and AFDC benefits), and constraints to working (e.g., the unemployment rate and health status).

The coefficient estimates for the probit equations for 1973 and 1988 are shown in Tables IA.1 and IA.2.

Estimates from these first-stage probit equations are used to construct a Heckman selectivity correction term $(\lambda)$ for each individual. The $\lambda$ variable is used in a second-stage earnings equation to correct for the potential bias in estimating an earnings equation using data only on individuals who work (i.e., individuals who have selected themselves into the work force).

The second-stage earnings equation is fit over those individuals with positive earnings, and the dependent variable is defined as the logarithm of observed earnings (LOGEARN). The log earnings equation is of the form:

$$
\text { LOGEARN }=X \beta_{1}+\text { HEALTH } * \beta_{2}+\mathrm{LN}(\text { HOURS }) * \beta_{3}+\lambda * c+\varepsilon
$$

where $\mathrm{X}$ consists of the independent (nonhealth) variables that affect earnings, HEALTH consists of two dummy variables measuring health status, LN(HOURS) equals the $\log$ of hours worked in the year, $\lambda$ is the selectivity correction term, and $\varepsilon$ is assumed to be a random residual term with $\mathrm{E}(\varepsilon)$ equal to zero. The independent variables $(\mathrm{X})$ in this equation were chosen using the human capital model as a guide, and include education, age, region of the country, rural-suburban-urban location, marital status, and number of children and their ages.

The estimated earnings equations for 1973 and 1988 are shown in Tables IB.1 and IB.2. Variable definitions are provided in Table IC.

\section{Predict Unadjusted Potential Earnings Capability $\left(\mathbf{P E C}_{\mathbf{i}}\right)$}


To obtain the potential earnings capability for a person $\left(\mathrm{PEC}_{\mathrm{i}}\right)$, we employ coefficients from the appropriate race-gender-specific log earnings (LOGEARN) equation and the person's demographic and human capital characteristics. The health status variables are set at levels indicating no disability/health limitation, the hours worked variable is set at 2,000 hours (50 weeks x 40 hours), and the coefficient on the $\lambda$ variable is not employed in the prediction. ${ }^{34}$ Unadjusted $\mathrm{PEC}_{\mathrm{i}}$ is of the form:

$$
\text { Unadjusted } \mathrm{PEC}_{\mathrm{i}}=\exp \left(\mathrm{X} \beta_{1}+\mathrm{LN}(2000) * \beta_{3}\right) \text {. }
$$

The resulting conditional value of predicted earnings for an individual assumes that he/she is healthy and is working full-time, full-year. By adopting this procedure, each individual with the same set of detailed human capital and demographic characteristics is assigned the same predicted log earnings.

\section{Adjust Potential Earnings Capability $\left(\mathbf{P E C}_{\mathrm{i}}\right)$ for Unemployment}

We recognize that there are exogenous constraints to working full-time, year-round even if a person is free of health limitations; therefore we make an adjustment to potential earnings capability. We adjust potential earnings capability for involuntary unemployment by assigning to each observation an estimate of their expected unemployment. These estimates of expected unemployment are calculated from reported involuntary unemployment data for groups described by race, gender, and education levels. A different expected unemployment rate is assigned to each demographic group to reflect the fact that people in these different groups face different levels of relative demand. Thus, unadjusted $\mathrm{PEC}_{\mathrm{i}}$ is multiplied by 1 minus the predicted unemployment rate. For example, if the unemployment rate for a person's racegender-education group is .05 , we multiply their predicted earnings capacity by .95 . Their adjusted $\mathrm{PEC}_{\mathrm{i}}$ is then 95 percent of the value estimated in 2. 


\section{Technical Adjustment to $\mathbf{P E C}_{\mathbf{i}}$}

The prediction obtained by taking the exponential of the estimated log earnings (LOGEARN) is the conditional median value. We are interested in the conditional mean value. In order to obtain the conditional mean from the conditional median, we multiply each predicted $\mathrm{PEC}_{\mathrm{i}}$ by $\exp \left(\sigma^{2} / 2\right)$, where $\sigma$ is the standard error of the regression. In our case, the estimate of $\sigma$ comes from a separately estimated racegender earnings equation (corrected for selection) fit over only full-time, full-year workers. So, potential earnings capacity or earnings capacity if healthy is of the form:

$$
\mathrm{PEC}_{\mathrm{i}}=\exp \left[\mathrm{X} \beta_{1}+\mathrm{LN}(2000)^{*} \beta_{3}\right]^{*}(1-\text { pred. ue rate }) * \exp \left(\sigma^{2} / 2\right)
$$

\section{Predict Actual Earnings Capability $\left(\mathrm{AEC}_{\mathrm{i}}\right)$ for the Disabled/Health-Limited Identified by the Work Limitation Criterion}

To calculate the actual earnings capability for the population with disabilities/health limitations, we first distinguish those with work limitations (see Appendix III). Then, for this group, we predict each individual's earnings given his/her actual disability/health limitations. In making this prediction, we follow the procedures used in estimating $\mathrm{PEC}_{\mathrm{i}}$, with three exceptions:

a. We utilize information on their health status (HEALTH) and the estimated effect of their health status on their wage $\left(\beta_{2}\right)$ in predicting log earnings (step 2 above).

b. We use their observed unemployment rate to adjust earnings capacity for unemployment rather than the expected unemployment for their race-gender-education group (step 3 above). ${ }^{35}$ We use observed unemployment for calculating $\mathrm{AEC}_{\mathrm{i}}$ because a person's disability/health limitation is likely to have a significant impact on the amount of time that they are involuntarily unemployed. 
c. We set the number of hours that a disabled/health-limited person is able to work (step 2 above) by relying on their own report of the number of weeks in the year they are unable to work due to a health limitation or disability. We call the number of weeks in which work is constrained due to disability/health limitations wc. To take wc into account when calculating actual earnings capability $\left(\mathrm{AEC}_{\mathrm{i}}\right)$, we multiply predicted earnings at 2,000 hours of work by $\Gamma$, where

$$
\Gamma=(50-\mathrm{wc}) / 50 .
$$

In summary, actual earnings capacity for people identified as disabled/health-limited by the work criterion are of the form:

$$
\begin{aligned}
& \mathrm{AEC}_{\mathrm{i}}= \\
& \exp \left[\mathrm{X} \beta_{1}+\mathrm{HEALTH} * \beta_{2}+\mathrm{LN}(2000) * \beta_{3}\right] *(1 \text { - act. ue rate }) * \exp \left(\sigma^{2} / 2\right) * \Gamma .
\end{aligned}
$$

\section{Predict Actual Earnings Capability $\left(\mathrm{AEC}_{\mathrm{i}}\right)$ for the Disabled/Health-Limited Identified by the Program Participation Criterion}

For people who were defined as disabled/health-limited due only to their receipt of some type of disability payment, the level of observed earnings is taken to be their actual earnings capability $\left(\mathrm{AEC}_{\mathrm{i}}\right)$. For these individuals:

$$
\mathrm{AEC}_{\mathrm{i}}=\text { observed earnings. }
$$

\section{Calculate Lost Earnings Capability $\left(\mathrm{LEC}_{\mathrm{i}}\right)$}

$\mathrm{LEC}_{\mathrm{i}}$ was estimated by subtracting actual earnings capability $\left(\mathrm{AEC}_{\mathrm{i}}\right)$ from potential earnings capability $\left(\mathrm{PEC}_{\mathrm{i}}\right)$. That is:

$$
\mathrm{LEC}_{\mathrm{i}}=\mathrm{PEC}_{\mathrm{i}}-\mathrm{AEC}_{\mathrm{i}} \text {. }
$$


For a small number of persons identified as disabled/health-limited by the program participation criteria, their actual earnings capability (observed earnings) was greater than their predicted healthy earnings capability. In these cases, we assumed that there was no loss in earnings capability due to their disability. 
TABLE IA.1

Probit Estimates of Determinants of Labor Force Participationa in 1973

\begin{tabular}{|c|c|c|c|c|c|c|c|c|}
\hline \multirow[b]{2}{*}{ Variable } & \multicolumn{2}{|c|}{$\begin{array}{c}\text { White Males } \\
(\mathrm{n}=30,407)\end{array}$} & \multicolumn{2}{|c|}{$\begin{array}{c}\text { Nonwhite Males } \\
(\mathrm{n}=4,538)\end{array}$} & \multicolumn{2}{|c|}{$\begin{array}{c}\text { White Females } \\
(\mathrm{n}=35,025)\end{array}$} & \multicolumn{2}{|c|}{$\begin{array}{l}\text { Nonwhite Females } \\
\quad(n=6,098)\end{array}$} \\
\hline & Coefficient & $\overline{\text { T-Ratio }}$ & Coefficient & $\overline{\text { T-Ratio }}$ & Coefficient & $\overline{\text { T-Ratio }}$ & Coefficient & $\overline{\text { T-Ratio }}$ \\
\hline ED & -0.026 & -1.17 & -0.020 & -0.44 & 0.101 & 5.09 & 0.068 & 2.29 \\
\hline EDSQ & 0.001 & 0.17 & -0.001 & -0.54 & 0.001 & 1.04 & 0.003 & 2.87 \\
\hline $\mathrm{AGE}$ & 0.060 & 10.55 & 0.109 & 6.34 & 0.031 & 6.39 & 0.074 & 6.66 \\
\hline AGESQ & -0.009 & -19.06 & -0.001 & -8.97 & -0.001 & -13.36 & -0.001 & -7.91 \\
\hline AGESCH & 0.00 & 5.03 & 0.001 & 1.33 & -0.001 & -3.82 & -0.001 & -3.17 \\
\hline NORTHEAST & -0.108 & -2.92 & 0.053 & 0.48 & -0.037 & -1.45 & -0.221 & -3.20 \\
\hline SOUTH & -0.211 & -6.10 & -0.068 & -0.81 & -0.040 & -1.64 & 0.151 & 2.76 \\
\hline WEST & -0.270 & -5.53 & -0.246 & -1.90 & -0.013 & -0.38 & -0.114 & -1.35 \\
\hline SUB & -0.023 & -0.90 & -0.012 & -0.18 & -0.045 & -2.52 & -0.127 & $-2 . .27$ \\
\hline CITY & -0.057 & -2.04 & -0.020 & -0.27 & -0.028 & -1.41 & -0.180 & -3.71 \\
\hline MARRIED & 0.101 & 3.18 & 0.158 & 2.26 & -- & -- & -- & -- \\
\hline $\mathrm{SNC}$ & -- & -- & -- & -- & 0.694 & 18.53 & 0.400 & 5.05 \\
\hline SWC & -- & -- & -- & -- & 0.334 & 9.01 & 0.066 & 1.17 \\
\hline MNC & -- & -- & -- & -- & 0.132 & 4.74 & -0.085 & -1.33 \\
\hline TOT & -- & -- & -- & -- & -0.682 & -27.73 & -0.376 & -7.20 \\
\hline NUMKID & 0.005 & 0.53 & 0.011 & 0.53 & -0.100 & -10.95 & -0.086 & -5.85 \\
\hline NONLAB & -0.006 & -3.12 & 0.008 & 1.17 & -0.022 & -21.633 & -0.017 & -4.73 \\
\hline SCHOOLLW & -0.580 & -6.57 & -1.198 & -7.56 & -0.584 & -6.714 & -0.589 & -3.52 \\
\hline OLD & -0.840 & -18.74 & -0.341 & -2.60 & -0.615 & -14.30 & -0.416 & -3.60 \\
\hline HEALTHPG & -0.802 & -25.934 & -1.179 & -16.49 & -0.544 & -13.24 & -0.914 & -14.09 \\
\hline WELFGEN & 0.001 & 3.02 & -0.001 & -1.76 & 0.001 & 0.26 & -0.001 & -0.17 \\
\hline UE & -0.037 & -2.12 & 0.043 & 0.87 & -0.019 & -1.52 & 0.001 & 0.04 \\
\hline ONE & 0.810 & 3.35 & -0.088 & -0.16 & -0.271 & -1.40 & -1.078 & -3.09 \\
\hline
\end{tabular}

Source: Estimates based on data from March 1974 CPS.

a Dependent variable equals one if individual reported earnings > \$1 in 1973 . 
TABLE IA.2

Probit Estimates of Determinants of Labor Force Participation ${ }^{\mathrm{a}}$ in 1988

\begin{tabular}{|c|c|c|c|c|c|c|c|c|}
\hline \multirow[b]{2}{*}{ Variable } & \multicolumn{2}{|c|}{$\begin{array}{c}\text { White Males } \\
(\mathrm{n}=34,527)\end{array}$} & \multicolumn{2}{|c|}{$\begin{array}{c}\text { Nonwhite Males } \\
(\mathrm{n}=7,869)\end{array}$} & \multicolumn{2}{|c|}{$\begin{array}{l}\text { White Females } \\
(\mathrm{n}=39,616)\end{array}$} & \multicolumn{2}{|c|}{$\begin{array}{l}\text { Nonwhite Females } \\
\quad(\mathrm{n}=10,189)\end{array}$} \\
\hline & Coefficient & T-Ratio & Coefficient & T-Ratio & Coefficient & T-Ratio & Coefficient & T-Ratio \\
\hline $\mathrm{ED}$ & 0.038 & 1.74 & -0.064 & -2.41 & 0.206 & 9.78 & 0.064 & 2.86 \\
\hline EDSQ & 0.001 & 1.15 & 0.002 & 2.24 & -0.001 & -1.34 & 0.004 & 5.52 \\
\hline AGE & 0.071 & 12.68 & 0.068 & 6.39 & 0.077 & 16.16 & 0.106 & 12.15 \\
\hline AGESQ & -0.001 & -21.47 & -0.001 & -10.56 & -0.001 & -22.72 & -0.001 & -13.59 \\
\hline AGESCH & 0.00 & -0.31 & 0.001 & 2.67 & -0.002 & -7.56 & -0.001 & -4.78 \\
\hline NORTHEAST & 0.034 & 1.07 & 0.155 & 2.03 & -0.139 & -5.72 & -0.150 & -2.70 \\
\hline SOUTH & -0.166 & -5.57 & 0.022 & 0.34 & -0.116 & -4.95 & 0.072 & 1.51 \\
\hline WEST & -0.186 & -6.24 & 0.226 & 3.46 & -0.034 & -1.44 & 0.181 & 3.56 \\
\hline SUB & 0.025 & 1.11 & 0.147 & 2.74 & 0.005 & 0.28 & -0.047 & -1.18 \\
\hline CITY & -0.063 & -2.26 & 0.086 & 1.84 & -0.011 & -0.47 & -0.059 & -1.68 \\
\hline MARRIED & -0.009 & -0.34 & 0.061 & 1.26 & -- & -- & -- & -- \\
\hline $\mathrm{SNC}$ & -- & -- & -- & -- & 0.267 & 7.11 & 0.040 & 0.65 \\
\hline SWC & -- & -- & -- & -- & 0.129 & 3.75 & -0.129 & -3.01 \\
\hline $\mathrm{MNC}$ & -- & -- & -- & -- & -0.078 & -2.42 & -0.200 & -3.57 \\
\hline TOT & -- & -- & -- & -- & -0.516 & -19.66 & -0.292 & -6.89 \\
\hline NUMKID & 0.003 & -0.23 & -0.040 & -2.16 & -0.167 & -13.23 & -0.142 & -8.23 \\
\hline NONLAB & 0.003 & 4.25 & 0.005 & 2.89 & -0.006 & -15.84 & 0.003 & -3.64 \\
\hline SCHOOLLW & -0.937 & -13.31 & -1.217 & -11.37 & -0.822 & -14.58 & -0.683 & -8.37 \\
\hline OLD & -0.536 & -12.91 & -0.397 & -3.95 & -0.422 & -10.60 & -0.246 & -2.70 \\
\hline HEALTHPG & -0.997 & -30.98 & -1.313 & -21.19 & -0.818 & -21.15 & -0.852 & -13.99 \\
\hline WELFGEN & -0.001 & -2.91 & -0.001 & -4.99 & -0.001 & -1.35 & -0.004 & -3.33 \\
\hline UE & -0.016 & -2.38 & -0.041 & -3.14 & -0.050 & -9.70 & -0.072 & -7.30 \\
\hline ONE & 0.329 & 1.41 & 1.051 & 3.16 & -1.335 & -6.60 & -1.247 & -4.58 \\
\hline
\end{tabular}

Source: Estimates based on data from March 1989 CPS.

a Dependent variable equals one if individual reported earnings > \$1 in 1988 . 
TABLE IB.1

Least Squares Estimates of Semilogorithmic Yearly Earnings Equations for 1973

\begin{tabular}{|c|c|c|c|c|c|c|c|c|}
\hline \multirow[b]{2}{*}{ Variable } & \multicolumn{2}{|c|}{$\begin{array}{c}\text { White Males } \\
(\mathrm{n}=25,255)\end{array}$} & \multicolumn{2}{|c|}{$\begin{array}{c}\text { Nonwhite Males } \\
(\mathrm{n}=3,759) \\
\end{array}$} & \multicolumn{2}{|c|}{$\begin{array}{l}\text { White Females } \\
(\mathrm{n}=17,138) \\
\end{array}$} & \multicolumn{2}{|c|}{$\begin{array}{c}\text { Nonwhite Females } \\
\quad(\mathrm{n}=3,347) \\
\end{array}$} \\
\hline & Coefficient & T-Ratio & Coefficient & $\overline{\text { T-Ratio }}$ & $\overline{\text { Coefficient }}$ & T-Ratio & Coefficient & $\overline{\text { T-Ratio }}$ \\
\hline ED & 0.006 & 0.72 & 0.016 & 1.03 & -0.033 & -1.92 & -0.065 & -3.05 \\
\hline EDSQ & 0.001 & 3.49 & 0.002 & 4.27 & 0.004 & 6.89 & 0.006 & 8.22 \\
\hline AGE & 0.050 & 18.84 & 0.057 & 8.07 & 0.040 & 10.25 & 0.040 & 4.45 \\
\hline AGESQ & -0.001 & -18.86 & -0.001 & -7.90 & -0.001 & -11.71 & -0.001 & -5.87 \\
\hline AGESCH & 0.001 & 6.02 & 0.00 & -0.99 & 0.00 & 1.30 & 0.00 & 1.12 \\
\hline NORTHEAST & 0.017 & 1.70 & 0.005 & 0.17 & 0.060 & 3.90 & 0.115 & 3.08 \\
\hline SOUTH & -0.023 & -2.28 & -0.075 & -2.94 & 0.012 & 0.77 & -0.191 & -6.35 \\
\hline WEST & 0.034 & 3.01 & 0.109 & 3.89 & 0.00 & -0.01 & 0.001 & 0.02 \\
\hline SUB & 0.219 & 24.96 & 0.310 & 10.52 & 0.177 & 13.03 & 0.242 & 6.65 \\
\hline CITY & 0.160 & 15.83 & 0.290 & 11.05 & 0.192 & 12.63 & 0.243 & 7.70 \\
\hline MARRIED & 0.171 & 13.66 & 0.120 & 4.38 & -- & -- & -- & -- \\
\hline $\mathrm{SNC}$ & -- & -- & -- & -- & 0.093 & 3.12 & -0.074 & -1.53 \\
\hline SWC & -- & -- & -- & -- & 0.035 & 1.35 & -0.072 & -2.23 \\
\hline $\mathrm{MNC}$ & -- & -- & -- & -- & 0.035 & 1.63 & -0.044 & -1.09 \\
\hline NUMKID & 0.025 & 7.91 & 0.010 & 1.56 & -0.040 & -4.56 & -0.018 & -1.52 \\
\hline LOG HOURS & 0.974 & 108.41 & 0.947 & 46.06 & 1.156 & 157.10 & 1.103 & 73.08 \\
\hline HEALTHPT & -0.193 & -2.38 & -0.416 & -2.74 & -0.085 & -0.68 & -0.102 & -0.72 \\
\hline HEALTHPY & -0.010 & -0.51 & -0.030 & -0.70 & 0.083 & 2.84 & -0.027 & -0.60 \\
\hline ONE & 0.100 & 0.90 & -0.101 & -0.42 & -1.313 & -7.66 & -0.749 & -2.60 \\
\hline LAMBDA & -0.387 & -11.90 & -0.408 & -6.33 & -0.007 & -0.21 & -0.077 & -1.03 \\
\hline R-squared & .532 & & .577 & & .655 & & .709 & \\
\hline
\end{tabular}

Source: Estimates based on data from March 1974 CPS. 
TABLE IB.2

Least Squares Estimates of Semilogarithmic Yearly Earnings Equations for 1988

\begin{tabular}{|c|c|c|c|c|c|c|c|c|}
\hline \multirow[b]{2}{*}{ Variable } & \multicolumn{2}{|c|}{$\begin{array}{c}\text { White Males } \\
(\mathrm{n}=27,086) \\
\end{array}$} & \multicolumn{2}{|c|}{$\begin{array}{c}\text { Nonwhite Males } \\
(\mathrm{n}=6,181) \\
\end{array}$} & \multicolumn{2}{|c|}{$\begin{array}{l}\text { White Females } \\
(\mathrm{n}=24,092) \\
\end{array}$} & \multicolumn{2}{|c|}{$\begin{array}{c}\text { Nonwhite Females } \\
(\mathrm{n}=6,112) \\
\end{array}$} \\
\hline & Coefficient & $\overline{\text { T-Ratio }}$ & Coefficient & T-Ratio & Coefficient & $\overline{\text { T-Ratio }}$ & Coefficient & T-Ratio \\
\hline ED & 0.050 & 4.38 & 0.006 & 0.50 & 0.093 & 6.47 & -0.061 & -4.13 \\
\hline EDSQ & 0.001 & 2.22 & 0.003 & 6.36 & 0.001 & 2.09 & 0.005 & 11.31 \\
\hline $\mathrm{AGE}$ & 0.055 & 18.53 & 0.055 & 10.15 & 0.064 & 18.82 & 0.039 & 6.10 \\
\hline AGESQ & -0.001 & -13.44 & -0.001 & -8.58 & -0.001 & -17.50 & -0.001 & -6.90 \\
\hline AGESCH & 0.00 & -0.82 & 0.00 & 0.69 & -0.001 & -3.03 & 0.001 & 3.10 \\
\hline NORTHEAST & 0.126 & 11.29 & 0.015 & 0.52 & 0.171 & 14.40 & 0.155 & 5.48 \\
\hline SOUTH & 0.014 & 1.34 & -0.167 & -6.58 & 0.055 & 4.90 & -0.038 & -1.54 \\
\hline WEST & 0.034 & 2.80 & -0.037 & -1.39 & 0.046 & 3.67 & 0.042 & 1.59 \\
\hline SUB & 0.208 & 23.32 & 0.137 & 6.42 & 0.206 & 21.80 & 0.151 & 7.36 \\
\hline CITY & 0.138 & 12.01 & 0.047 & 2.46 & 0.173 & 14.40 & 0.140 & 7.42 \\
\hline MARRIED & 0.143 & 13.21 & 0.100 & 4.90 & -- & -- & -- & -- \\
\hline $\mathrm{SNC}$ & -- & -- & -- & -- & 0.016 & 0.84 & -0.014 & -0.39 \\
\hline SWC & -- & -- & -- & -- & -0.019 & -1.14 & -0.070 & -3.30 \\
\hline $\mathrm{MNC}$ & -- & -- & -- & -- & -0.049 & -2.89 & -0.065 & -2.20 \\
\hline NUMKID & 0.020 & 4.68 & 0.003 & 0.36 & -0.078 & -9.61 & -0.031 & -2.66 \\
\hline LOG HOURS & 0.918 & 131.06 & 1.049 & 75.71 & 1.040 & 210.49 & 1.070 & 112.62 \\
\hline HEALTHPT & -0.186 & -1.48 & -0.395 & -2.09 & -0.111 & -1.23 & 0.071 & 0.41 \\
\hline HEALTHPY & -0.001 & -0.04 & 0.011 & 0.24 & -0.040 & -1.51 & 0.033 & 0.75 \\
\hline ONE & 0.670 & 5.53 & -0.003 & -0.02 & -1.023 & -6.99 & 0.205 & 0.98 \\
\hline LAMBDA & -0.367 & -10.95 & -0.037 & -0.66 & 0.167 & 5.15 & 0.060 & 1.02 \\
\hline R-squared & .546 & & .605 & & .712 & & .748 & \\
\hline
\end{tabular}

Source: Estimates based on data from March 1989 CPS. 


\section{TABLE IC}

\section{Alphabetical Listing of Variable Definitions}

AGE

AGESCH

AGESQ

CITY

ED

EDSQ

HEALTHPG

HEALTHPT -

HEALTHPY -

LAMBDA -

LOG HOURS -

MARRIED -

MNC

MWC
Age in single years.

Age times number of years of schooling completed.

Age squared.

Dummy variable equal to 1 if from central city.

Number of years of schooling beyond kindergarten completed.

Number of years of schooling beyond kindergarten completed, squared.

Dummy variable equal to 1 if person participates in disability program.

Program participation:

1. Receives Social Security or Railroad Retirement benefits and

a. is not in school, is age 19-22, and is not widowed, divorced, or separated with dependent children; or

b. is age 23-59, and is not widowed, divorced, or separated with dependent children.

2. For 1980 and 1988, receives SSI. For 1973, receives welfare/public assistance and is not unemployed and not separated, divorced, or widowed with dependent children.

3. Receives Workers' Compensation.

4. Receives income from a veterans' disability program, is a veteran, and is not in school.

Dummy variable equal to 1 if person limited to part-time work for health reasons.

Dummy variable equal to 1 if person limited to part-year work for health reasons.

Selectivity correction variable.

Natural log of total hours worked in the year. Total hours equals (\# of weeks worked in year) X (\# of hours usually worked per week). For 1973, we only have information on individual's part-time/full-time status and weeks worked category (e.g., 1-13 weeks). The mean of the person's weeks worked category is multiplied by 20 if he/she was a part-time worker and 40 if a full-time worker to obtain to total hours worked in 1973.

Dummy variable equal to 1 if person married, spouse present.

Dummy variable equal to 1 if married, no children < age 18 .

Dummy variable equal to 1 if married, with children $<$ age 18 . 


\section{TABLE IC (continued)}

NONLAB - $\quad$ Nonlabor income equals family income minus individual's earnings minus family income dependent on individual's labor supply decision (in thousands of dollars).

NORTHEAST - $\quad$ Dummy variable equal to 1 if from Northeast region of the country.

NOTID - $\quad$ Dummy variable equal to 1 if survey doesn't identify whether individual is from city, suburb, or rural area.

NUMKID $\quad-\quad$ The number of own, never-married children under 18.

OLD - $\quad$ Dummy variable equal to 1 if person age 65 or older.

ONE $\quad$ - $\quad$ Constant, equal to 1 for everyone.

SCHOOLLW - $\quad$ Dummy variable equal to 1 if school was major activity last week.

SNC $\quad-\quad$ Dummy variable equal to 1 if single, no children $<$ age 18.

SOUTH - $\quad$ Dummy variable equal to 1 if from Southern region of country.

SUB - - Dummy variable equal to 1 if from metropolitan area, but not central city.

SWC $\quad-\quad$ Dummy variable equal to 1 if single with children < age 18.

TOT - $\quad$ Dummy variable equal to 1 if have a child $<$ age 6.

UE - $\quad$ State unemployment rate. For 1973, individuals are only identified as being from one of 23 groups of states. The UE rate reported for them is a weighted average (by population) of the group's UE rates.

WELFGEN - $\quad$ Maximum state AFDC payment for a family of four. For 1973, individuals are only identified as being from one of 23 groups of states. The AFDC benefits reported for them is a weighted average (by population) of the group's AFDC benefits.

WEST - $\quad$ Dummy variable equal to 1 if from West region of country. 


\section{APPENDIX II \\ Empirical Procedures for Estimating Lost Potential Earnings from Disability/Health Limitations Using SIPP Data}

The estimates of LPE for 1984 are based on data from the Survey of Income and Program Participation (SIPP). Health data are from the topical module of the Third Wave, and labor force data are from August 1984. While the labor force data are comparable to those in the CPS, the health data are much richer. The SIPP includes self-reported health status and functional ability, or Activities of Daily Living (ADLs)--including ADLs and instrumental ADLs. Our sample includes all persons aged 19-64, excluding those under 25 in school. ${ }^{36}$ Descriptive statistics and variable definitions are in Table IIA.1. Our procedure for estimating LPE with these data is analogous to that used for the CPS (See Appendix I), but it differs in several respects.

\section{Estimate Potential Earnings Capability $\left(\mathbf{P E C}_{\mathrm{i}}\right)$}

To estimate potential earnings capability for an individual $\left(\mathrm{PEC}_{\mathrm{i}}\right)$, we fit an identical twoequation model for males and females. The methodology is identical to that in Wolfe and Hill (forthcoming). It involves a tobit two-stage model of hours worked and wages. This model is similar to the probit two-stage model used for the 1973 and 1988 estimates, except that the first equation is a tobit specification of the number of hours worked, and the second equation estimates the wage rate. We use this different model because it allows us to estimate reductions in hours of work due to disability/health limitations, controlling for other factors. The greater detail of the SIPP data, which asks for health status independently of labor force factors, and for hours and weeks worked, allows us to estimate such effects. Like the probit model, the tobit two-stage model takes into account the fact that a number of individuals do not participate in the paid labor force. These persons have both zero hours of work and zero wages.

The log of weekly hours worked is the dependent variable of the first equation. 


$$
\ln (\text { Hours })=X_{1} \beta_{1}+\text { Health } \beta_{2}+\varepsilon_{1} \text {. }
$$

It is estimated as a maximum likelihood tobit equation which takes into account the truncation at zero hours. The vector $\mathrm{X}_{1}$ of independent variables included in the hours equation is designed to measure alternative time demands (number of children under age 6 and aged 6-18; the presence of a disabled child), labor market conditions (unemployment rate), human capital (education, experience prior to 1984), other personal characteristics (race measured as two variables, Hispanic and black), and the incentive to work (other income). The health variables measure poor or fair health and ADLs.

The estimated tobit log hours equations for 1984 are shown in Table IIA.2.

The second-stage equation is fit over those individuals with positive hours worked.

$$
\ln (\text { wage })=\mathrm{X}_{2} \gamma_{1}+\text { Health } \gamma_{2}+\lambda \gamma_{3}+\varepsilon_{2}
$$

The dependent variable is the log of wages from the individual's main job. The vector $\mathrm{X}_{2}$ of independent variables includes human capital, personal characteristics, and labor market conditions. Health status variables are the same as in the first equation. The two-stage model includes a selection control, $\lambda$, which is identical to the more commonly used one based on a probit equation of labor force participation (see Appendix I), except that the tobit parameter estimates from the first stage are used in the normal distribution and density (see Maddala, 1983, p. 240).

The estimated log wage equations for 1984 are shown in Table IIA.2.

\section{Predict Unadjusted Potential Earnings Capability $\left(\mathbf{P E C}_{\mathrm{i}}\right)$}

Unadjusted potential earnings capability is the product of the predicted wage, setting the health status variables in the estimated wage equation at levels indicating no disability/health limitation (or, equivalently, $\beta_{2}=0$ ), and 2,000 hours of annual work. The coefficient on the lambda variable, $\gamma_{3}$, is not employed in the prediction. 


\section{Adjust Potential Earnings Capability $\left(\mathbf{P E C}_{\mathrm{i}}\right)$ for Unemployment}

This adjustment is identical to that in Appendix I, and the 1984 employment rates are for categories identical to those used in the 1973 and 1988 estimations.

\section{Technical Adjustment}

The same adjustment as that employed in Appendix I (step 4) is applied to the estimated wage rate. In this case, the estimate of $\sigma$ is the standard error of the wage regression.

\section{Predict Actual Earnings Capability $\left(\mathrm{AEC}_{\mathrm{i}}\right)$ for Persons with Poor or Fair Health or One or More ADL Limitations}

To obtain actual earnings capability $\left(\mathrm{AEC}_{\mathrm{i}}\right)$, we adjust both the wages and hours worked.

Predicted actual wages are estimated by using all the coefficients from the wage equation, save that on the selectivity term, $\gamma_{3}$. We use the hours equation to obtain estimated actual weekly capacity hours for each individual. For persons with poor or fair health or one or more ADLs, we reduce their weekly healthy capacity hours of work (40 hours) using the coefficients on the health variables, $\gamma_{2}$. Actual earnings capability hours for a year are obtained by multiplying by 50 weeks. The unemployment and technical adjustments are identical to those for healthy earnings capacity in steps 3 and 4.

\section{Calculate Lost Potential Earnings $\left(\mathbf{L E C}_{\mathrm{i}}\right)$}

$\mathrm{LEC}_{\mathrm{i}}$ was estimated by subtracting actual earnings capability $\left(\mathrm{AEC}_{\mathrm{i}}\right)$ from potential earnings capability $\left(\mathrm{PEC}_{\mathrm{i}}\right)$. 
TABLE IIA.1

\section{Definitions and Mean Values of Variables Used in the Model of Earnings Capability for 1984}

\begin{tabular}{|c|c|c|c|c|c|}
\hline Variable & Description & $\begin{array}{l}\text { Men } \\
\text { Mean } \\
\text { (S.D.) }\end{array}$ & $\begin{array}{l}\text { Men with } \\
\text { Hours }>0 \\
\text { Mean } \\
\text { (S.D.) }\end{array}$ & $\begin{array}{l}\text { Women } \\
\text { Mean } \\
\text { (S.D.) }\end{array}$ & $\begin{array}{l}\text { Women with } \\
\text { Hours }>0 \\
\text { Mean } \\
\text { (S.D.) }\end{array}$ \\
\hline $\mathrm{N}$ & & 11,658 & 9,504 & 13,077 & 7,416 \\
\hline ln Hours & Natural log of usual weekly hours worked & $\begin{array}{l}3.2 \\
(1.3)\end{array}$ & & $\begin{array}{l}2.3 \\
(1.7)\end{array}$ & \\
\hline ln Wage & $\begin{array}{l}\text { Natural log of hourly wage at main job in } \\
\text { August } 1984\end{array}$ & & $\begin{array}{l}2.33 \\
(.80)\end{array}$ & & $\begin{array}{l}1.81 \\
(.69)\end{array}$ \\
\hline \multicolumn{6}{|c|}{ Health measures } \\
\hline$\overline{\mathrm{ADLs}}$ & $\begin{array}{l}\text { Number of activities of daily living the } \\
\text { subject has difficulty performing. The } \\
\text { eight activities are: reading with glasses } \\
\text { or contact lenses, hearing normal-volumed } \\
\text { conversation, having one's speech understood, } \\
\text { walking a quarter mile, lifting ten pounds, } \\
\text { climbing a flight of stairs, moving without } \\
\text { a walking aid, and getting around outside } \\
\text { one's home. }\end{array}$ & $\begin{array}{l}.27 \\
(.84)\end{array}$ & $\begin{array}{l}.13 \\
(.48)\end{array}$ & $\begin{array}{l}.32 \\
(.91)\end{array}$ & $\begin{array}{l}.16 \\
(.54)\end{array}$ \\
\hline Poor-Fair & Indicator for self-reported poor or fair health & $\begin{array}{l}.11 \\
(.32)\end{array}$ & $\begin{array}{l}.06 \\
(.25)\end{array}$ & $\begin{array}{l}.13 \\
(.33)\end{array}$ & $\begin{array}{l}.08 \\
(.27)\end{array}$ \\
\hline \multicolumn{6}{|c|}{ Personal characteristics } \\
\hline Hispanic & Indicator & $\begin{array}{l}.05 \\
(.21)\end{array}$ & $\begin{array}{l}.05 \\
(.21)\end{array}$ & $\begin{array}{l}.05 \\
(.22)\end{array}$ & $\begin{array}{l}.04 \\
(.20)\end{array}$ \\
\hline Black & Indicator & $\begin{array}{l}.09 \\
(.29)\end{array}$ & $\begin{array}{l}.08 \\
(.27)\end{array}$ & $\begin{array}{l}.11 \\
(.32)\end{array}$ & $\begin{array}{l}.11 \\
(.31)\end{array}$ \\
\hline Married & Indicator & $\begin{array}{l}.69 \\
(.46)\end{array}$ & & $\begin{array}{l}.65 \\
(.48)\end{array}$ & \\
\hline
\end{tabular}

(table continues) 
TABLE IIA.1 (continued)

\begin{tabular}{|c|c|c|c|c|c|}
\hline Variable & Description & $\begin{array}{l}\text { Men } \\
\text { Mean } \\
\text { (S.D.) }\end{array}$ & $\begin{array}{l}\text { Men with } \\
\text { Hours >0 } \\
\text { Mean } \\
\text { (S.D.) }\end{array}$ & $\begin{array}{l}\text { Women } \\
\text { Mean } \\
\text { (S.D.) }\end{array}$ & $\begin{array}{l}\text { Women with } \\
\text { Hours }>0 \\
\text { Mean } \\
\text { (S.D.) }\end{array}$ \\
\hline
\end{tabular}

$\underline{\text { Human capital }}$

Education Years of schooling

12.7

13.0

12.4

12.9

$(3.0)$

(2.9)

Education $^{2}$

172

(76)

178

162

172

(67)

Prior Experience For those with higher educations, years since last attended college; otherwise

Age - max (Education +6, 16)

$\begin{array}{llll}18 & 17 & 18 & 16 \\ (13) & (13) & (13) & (13) \\ 510 & 448 & 512 & 424 \\ (604) & (541) & (594) & (552)\end{array}$

Prior Experience ${ }^{2}$

$\underline{\text { Regions }}$

Midwest

Indicator

$\begin{array}{llll}.26 & .26 & .26 & .26 \\ (.44) & (.44) & (.44) & (.44)\end{array}$

South Indicator

.32

$$
.32
$$

$(.47)$

.33

(.47)

.34

$.19 \quad .19$

.19

West

Indicator

(.40)

(.39)

(.39)

.19

(.39)

Unemployment

Rate

MSA rates for MSA residents, and state rates otherwise, averaged over four months.

$\begin{array}{llll}7.3 & 7.2 & 7.3 & 7.2 \\ (2.3) & (2.3) & (2.3) & (2.2)\end{array}$

Time demands

\# Kids <6

Number of children under age 6

.31

.36

(.66)

\# Kids 6-17 Number of children age 6 to 17

.53

.63

(.92)

(.98)

(table continues) 
TABLE IIA.1 (continued)

\begin{tabular}{llllll}
\hline & & & \multicolumn{2}{c}{ Women with } \\
& & & Men with & \\
& & Men & Hours $>0$ & Women Hours $>0$ & Mean \\
Variable & Description & Mean & Mean & Mean & Mean \\
& & (S.D.) & (S.D.) & (S.D.) & (S.D.)
\end{tabular}

Disabled Child Indicator of whether any child has either a long-lasting physical condition that limits walking, running, or playing, or a longlasting mental or emotional problem that limits learning or schoolwork.

.03

Other income (000's)

Person's Other Person's monthly unearned income (in 1984 dollars), less public transfers, averaged over four months, where negative values are excluded.

Spouse's Earned Spouse's monthly earned income (in 1984 dollars), averaged over four months, where negative values are excluded.

Spouse's Other Spouse's monthly unearned income (in 1984 dollars), averaged over four months, where negative values are excluded.

Source: Survey of Income and Program Participation, 1984 Panel, August. 
TABLE IIA.2

Estimated Model of Earnings Capability for 1984:

Two-Stage Tobit Estimates

\begin{tabular}{|c|c|c|c|c|}
\hline & \multicolumn{2}{|c|}{$\begin{array}{c}\text { Men } \\
(\mathrm{n}=11,658)\end{array}$} & \multicolumn{2}{|c|}{$\begin{array}{c}\text { Women } \\
(\mathrm{N}=13,077) \\
\end{array}$} \\
\hline & Ln Hours & $\operatorname{Ln~Wage~}^{a}$ & Ln Hours & Ln Wages $^{a}$ \\
\hline Constant & $2.43(.11)^{* *}$ & $.87(.13)^{* *}$ & $1.45(.23)^{* *}$ & $1.38(.13)^{* *}$ \\
\hline \multicolumn{5}{|l|}{ Health measures } \\
\hline Poor-Fair & $-.69(.04)^{* *}$ & $-.07(.04)$ & $-.57(.08) * *$ & $-.13(.04) * *$ \\
\hline ADLs & $-.47(.02)^{* *}$ & $.02(.02)$ & $-.55(.03) * *$ & $-.03(.02)$ \\
\hline \multicolumn{5}{|l|}{ Personal characteristics } \\
\hline Hispanic & $-.03(.05)$ & $-.15(.04)^{* *}$ & $-.17(.10)^{*}$ & $.08(.05)$ \\
\hline Black & $-.50(.04)^{* *}$ & $-.22(.04) * *$ & $-.14(.07)^{*}$ & $.10(.03) * *$ \\
\hline Married & $.44(.03)^{* *}$ & & $-.27(.06)^{* *}$ & \\
\hline \multicolumn{5}{|l|}{ Human capital } \\
\hline Education & $.08(.02)^{* *}$ & $-.01(.01)$ & $.17(.03)^{* *}$ & $-.03(.02)^{*}$ \\
\hline Education $^{2}$ & $-.002(.001)^{* *}$ & $.004(.001)^{* *}$ & $-.001(.001)$ & $.005(.001) * *$ \\
\hline Prior Experience & $.035(.003)^{* *}$ & $.046(.003)^{* *}$ & $.04(.01)^{* *}$ & $.022(.003)^{* *}$ \\
\hline Prior Experience ${ }^{2}$ & $-.0009(.0001)$ & $-.0006(.0001)^{* *}$ & $-.0014(.0001)^{* *}$ & $-.0004(.0001)^{* *}$ \\
\hline \multicolumn{5}{|l|}{ Regions } \\
\hline Midwest & $.07(.03)^{*}$ & $-.06(.03)^{*}$ & $.20(.06) * *$ & $-.08(.03)^{* *}$ \\
\hline South & $.13(.03)^{* *}$ & $-.06(.03)^{* *}$ & $.30(.06) * *$ & $-.10(.03)^{* *}$ \\
\hline West & $.04(.03)$ & $.04(.03)$ & $.20(.07)^{* *}$ & $.02(.03)$ \\
\hline Unemployment Rate & $-.027(.005)^{* *}$ & $-.004(.004)$ & $-.08(.01)^{* *}$ & $-.012(.004) * *$ \\
\hline \multicolumn{5}{|l|}{ Time demands } \\
\hline \# Kids $<6$ & $-.03(.02)^{*}$ & & $-.93(.03) * *$ & \\
\hline \# Kids 6-18 & $.001(.010)$ & & $-.18(.02)^{* *}$ & \\
\hline Disabled Child & $-.10(.07)^{*}$ & & $-.005(.120)$ & \\
\hline \multicolumn{5}{|l|}{ Other income (000's) } \\
\hline Person's Other & $-.24(.01)^{* *}$ & & $-.17(.02)^{* *}$ & \\
\hline Spouse's Earned & $-.001(.005)$ & & $-.034(.004) * *$ & \\
\hline Spouse's Other & $.06(.01)^{* *}$ & & $-.17(.02)^{* *}$ & \\
\hline Sigma & $1.17(.01)$ & & $2.21(.02)$ & \\
\hline$\lambda$ & & $.12(.03)^{* *}$ & & $-.03(.04)$ \\
\hline Covariance & .17 & & -.05 & \\
\hline Log likelihood & $-17,920$ & & $-22,782$ & \\
\hline
\end{tabular}

Source: Estimates based on data from survey of Income and Program Participation, 1984 Panel, August.

** Significant at 5\% level; * significant at $10 \%$ level.

Note: Standard errors in parentheses.

${ }^{a}$ Calculated only for those with hours $>0$. 


\section{APPENDIX III \\ Defining the Population of Persons with Health Problems/Disabilities in the Current Population Survey}

We identified any person aged 18 to 64 as having a long-term disability or health limitation if they met at least one of either our work limitation criteria or disability program participation criteria. The criteria for 1973 and 1988 are close, but not exactly the same due to changes in the CPS questionnaire during the fifteen year period between the years of interest.

\section{Criteria}

\section{Work Limitation}

-did not work last year and stated that the main reason why he/she did not work was because they were unable to work.

-worked part-time (1-34 hours) last week, who usually works part-time, and who stated that the main reason why he/she worked part-time was because of their own health problems.

-worked part-year (less than 50 weeks) and stated that the main reason why he/she worked partyear was because of illness.

\section{Disability Program Participation}

-received income from a public transfer program and had other characteristics that indicated that the transfer was due to a disability or an illness. In particular, individuals not identified in the prior categories were included in this category if:

-they received welfare (public assistance) income, were not separated, widowed, or divorced and had a child less than 18 years of age, and were not unemployed full-time any time during the year (this categorization is an attempt to identify those receiving Aid to the Blind or Disabled, the forerunner of the Supplemental Security Income [SSI] program).

-they received Social Security (or Railroad Retirement) income, were aged 19-22, were not widowed with a child less than age 18, and school was not the main activity last week and school is not the main reason why they did not work last year (this categorization is an attempt to identify those receiving Social Security benefits for disabled children of beneficiaries).

-they received Social Security (or Railroad Retirement) income, were aged 23-59, and were not widowed with own children under age 18 (This categorization is an attempt to identify those 
receiving benefits under the Social Security Disability Insurance and the Railroad Retirement programs, which support individuals of working age who are permanently and totally disabled).

-they received Workers' Compensation benefits.

-they received income from a veterans program, were a veteran, and school was not the main activity last week and school is not the main reason why they did not work last year (this categorization is an attempt to identify those receiving Veterans' Disability benefits).

\section{Criteria}

\section{Work Limitation}

-did not work and stated that the main reason why he/she did not work was because they were unable to work.

-usually worked fewer than 35 hours a week last year and stated that the main reason why he/she worked part-time was because of their own health problems.

-had a total of weeks worked plus weeks looking for work of less than 50, and stated that the main reason why he/she was not working or looking for work in the remaining weeks was because of their own health problems.

\section{Disability Program Participation}

-received income from a public transfer program and had other characteristics that indicated that the transfer was due to a disability or an illness. In particular, individuals not identified in the prior categories were included in this category if:

-they received SSI benefits

-they received Social Security (or Railroad Retirement or disability or survivors) income, were aged 19-22, were not widowed with a child less than age 18, and school was not the main activity last week and school is not the main reason why they did not work last year (this categorization is an attempt to identify those receiving Social Security benefits for disabled children of beneficiaries).

-they received Social Security (or Railroad Retirement or disability or survivors) income, were aged 23-59, and were not widowed with own children under age 18 (this categorization is an attempt to identify those receiving benefits under the Social Security Disability Insurance and other disability-related programs, which support individuals of working age who are permanently and totally disabled).

-they received Workers' Compensation benefits (but not from their own insurance). 
-they received Veterans' Disability payments, were a veteran, and school was not the main activity and school is not the main reason why they did not work last year (this categorization is an attempt to identify those receiving Veterans's Disability benefits). 


\section{Notes}

${ }^{1}$ The appropriate measure of disability for labor market analysis concerns the inability to carry out a specific task or job, and may take into account the stress level of a job. Disability is not simply an impairment--a persistent abnormality of physiological function--it is job-related. This definition of disability combines information on physical and mental conditions with job requirements; thus it is based in part on job environment and in part on impairments and functional limitations (see Wolfe [1984]). Haveman, Halberstadt, and Burkhauser (1984) emphasize three issues in defining disability: (1) establishing the physical and mental characteristics on which ability is judged, (2) setting a norm for the able-bodied, and (3) defining the deviation from the norm required for classifying persons as disabled.

${ }^{2}$ An individual's earning capability is also part of the determination. The largest of these programs--the Social Security Disability Insurance program and the Supplemental Security Income program for disabled persons--employ a very strong version of this standard. Eligibility for benefits from these programs requires that persons be "permanently and totally disabled"; earnings of more than $\$ 500$ per month is taken as evidence that this stringent standard is not being met.

${ }^{3}$ See Cooper and Rice (1976), Rice, Hodgson, and Kopstein (1985), and Rice, Kelman, and Miller (1991) for examples. Other recent works address the economic costs of new cases of illness or incidence of disease rather than all existing illness or disability (prevalence). See Hartunian, Smart, and Thompson (1981) for a review of earlier studies as well as their study of the economic costs of new cases of four specific diseases and Manning et al. (1989) for a study of the cost of poor health habits such as drinking and smoking. Incidence studies produce a present discounted value of the cost of illness (injury, drinking) based on the year in which the 'incident' occurs.

${ }^{4}$ Rice, Hodgson, and Kopstein were not consistent in their methodology. In their 1985 study, they imputed the value of lost household production to employed persons in 1980, but in the 1976 analysis 
(by Cooper and Rice), they imputed it only to full-time housewives in 1972. The 1976 study applied full-employment rates from 1970, but the 1985 study applied the actual employment rates of 1980 . The Rice methodology is more completely described in Section II B below.

${ }^{5}$ The detailed description of procedures is lengthy because we present loss estimates both over time (using the Current Population Survey [CPS]) and at a point in time using a range of definitions of limitations (using the Survey of Income and Program Participation [SIPP]).

${ }^{6}$ Viewed alternatively, with a change in sign, this value is the gain in aggregate work force productive capability if all existing disability/health limitations were eliminated.

${ }^{7}$ A recent Rand study of the cost of accidental injuries (Hensler et al., 1991) also assumes that injury does not influence a person's wage rate; however, the authors do this for measuring the value of sick leave rather than other reductions in labor market activity.

${ }^{8}$ This problem may also create a downward bias in their estimate of the wage rate if healthy $\left(\mathrm{w}_{\mathrm{i}}^{\mathrm{F}}\right)$, in that full-time, full-year workers include individuals whose illnesses or disabling conditions affect only the type, if not the amount, of work that they perform.

${ }^{9}$ Rice et al. do not assume that if all people were healthy, they would work in the paid labor force, however. LE for each age-gender group is multiplied by the percentage of the age-gender group with positive earnings.

${ }^{10}$ Hensler et al. use the wage rate of demographically matched labor force participants as the basis of their estimates of morbidity. A sensitivity test for those 65 plus and females suggested that this approach overstated the earnings loss by about 15 percent (pp. 186-187).

${ }^{11}$ Since Rice et al. apply a wage rate to household services, they might find an intertemporal increase in LE among women due to higher wages in the paid labor force.

${ }^{12}$ This issue is also relevant in estimating the present discounted value of losses due to disability 
over time--an approach used by Rice and associates in their work, as well as those conducting incidence studies.

${ }^{13}$ It should be noted, however, that we do not control for changes in the returns to the services of human capital of those in the paid labor force $\left(\mathrm{w}^{\mathrm{P}}\right)$ or for changes in the preferences or human capital returns for persons with disabilities/health limitations. Moreover, to the extent that the wage rates we observe reflect prior labor force experience which itself is influenced by prior tastes, attitudes, and transfer programs, our estimates may to some extent reflect these point-in-time effects. Our wage rates do reflect changes in wages due to changes in discrimination, which are not productivity-caused changes in wages.

${ }^{14}$ Rice et al. also adjust earnings for earnings supplements (i.e., fringe benefits) with a flat percentage multiplier across all groups; we do not make such an adjustment.

${ }^{15}$ We would also note that the present discounted value of the loss calculated by Rice et al. implicitly assumes that the work choices made by a person over his/her lifetime correspond to the choices made by current cohorts of a particular age. In fact, both labor force participation rates and work hours of males and females have changed substantially over time.

${ }^{16}$ Rice et al. rely on the less detailed comparisons because of the limited information on age and sex available from death records, and the desire to use the same methodology to value both morbidity and mortality losses. Our focus on disability/health limitations--as opposed to illness--does not require the calculation of mortality losses, and in any case, the human capital approach to estimating the value of years of life lost lacks a strong theoretical foundation.

${ }^{17}$ This last term is obtained from a probit estimate fit over all working-age people for each genderrace group, distinguishing those with positive earnings from those who do not work, and is introduced into the relevant gender-race earnings equation to correct for the potential bias in estimating an 
earnings equation using data only on individuals who work (i.e., individuals who have selected themselves into the work force).

${ }^{18}$ Predictions from the estimated earnings equations are unconditional, using the coefficients estimated with the selectivity variables included in the equations but not the coefficients on the selectivity variables.

${ }^{19}$ This predicted value of potential earnings capability is then adjusted downward to reflect the constraint on full-time, full-year work imposed by involuntary unemployment, using information in the CPS regarding the number of weeks of expected unemployment for the individual, given his/her racegender-education characteristics. See Appendix I for the detailed procedures for this adjustment.

${ }^{20}$ This predicted earnings level is adjusted for involuntary unemployment using the same procedure as for $\mathrm{PEC}_{\mathrm{i}}$, described in note 19 .

${ }^{21}$ Details on this estimating procedure are provided in Appendix II.

${ }^{22}$ The detailed procedures used for obtaining the estimates from the SIPP data, including the technical adjustments for taking antilogs and reflecting work constraints due to involuntary unemployment, are presented in Appendix II.

${ }^{23}$ Again, the unemployment adjustment is identical to that used in obtaining $\mathrm{PEC}_{\mathrm{i}}$.

${ }^{24}$ For this panel, SIPP interviewed a nationally representative sample of twenty-thousand households once every four months for 2.5 years, beginning in October 1983. Labor force data were regularly collected for this sample, but only in 1984 were sufficiently detailed health data collected to permit an estimate of the extent of health/disability problems.

${ }^{25} \mathrm{~A}$ detailed description of the definition is provided in Appendix III.

${ }^{26} \mathrm{~A}$ recent report by the U.S. Bureau of the Census (1989) estimates the disabled/health-limited working-age population from 1981 through 1988, also using the CPS. The population with limitations in this study is composed of those persons less than age 65 who respond positively to the question 
"Do you have a health problem or disability which prevents you from working or which limits the kind or amount of work you can do?", plus those who report receiving SSI or Medicare. The pattern over time in the prevalence of disability by this definition is similar to that in Table 1 , and the prevalence rate for males in that report also exceeds that for females.

The National Health Interview Survey (NHIS) data, which are used by many researchers to measure both the extent of disability and changes in it over time (Chirikos, 1989), indicate that 13.6 percent of the population aged 18-64 had some activity limitation in 1973, and that this decreased to 12.8 percent in 1988 . If the disabled are restricted to those with a "major" limitation, the percentages in the two years become 10.0 and 9.3. Much of the reduction is among individuals aged 45-64.

The largest difference between the NHIS and our CPS estimate is for women. Our CPS-based definition rests upon a limitation in the ability to work, while the NHIS definition includes any activity or major activity limitation. Hence, some women who may have a health/disability condition but who have never been regular labor force participants may be excluded from our CPS-based definition. Our SIPP-based estimates do not rely on a work-related definition, and they reveal higher levels of disability and health problems among women.

${ }^{27}$ These incorporate both ADLs and instrumental ADLs and they include difficulty in, for example, lifting ten pounds, seeing with the aid of corrective lenses, hearing normal-volumed conversation, and walking a quarter of a mile.

${ }^{28}$ All dollar figures are reported in 1988 dollars.

${ }^{29}$ Although not shown in the tables, the factor that changed substantially over this period was the reduction in average male potential earnings capability (PEC), a pattern that reflects the erosion in the average real earnings of full-time, full-year employed males over this period.

${ }^{30}$ As noted above, the CPS limitation criterion relies in part on self-reported work limitations and in part on participation in disabilityrelated transfer programs; as a result it probably underestimates the number of women who are classified as limited. Because the program 
participation component of the CPS criterion generally requires a prior work history, LEC as a proportion of potential earnings capability is greater for females than males using CPS. The SIPP definitions are independent of work-related considerations.

${ }^{31}$ It should be emphasized, however, that the two populations are probably quite different in the composition of their limitation characteristics. There is little reason that the CPS definition and the two plus ADL definition should identify the same populations of persons with limitations.

${ }^{32}$ Our mean loss in earnings capability (LEC) can be compared to the calculations of Chirikos (1989). Our calculated mean LEC among disabled/health-limited people is $\$ 11,600$ for 1988 . This is substantially larger than Chirikos' estimate of the mean loss of earnings due to health-related limitations of \$6,500 (1988 dollars). (Chirikos' estimates are calculated from his Tables 1 and 2c.) An average which excludes Chirikos' working youth population (ages 15-24) does not substantially raise the mean. A major cause of this difference is that the estimated eamings of persons with no limitations (the denominator of his ratio) do not reflect work hours that are at levels equal to their capabilities; for example, low labor force participation rates among women reduce Chirikos' mean. However, our mean LEC among males with limitations is $\$ 14,200$ (not shown), about 131 percent of Chirikos' estimate of $\$ 10,800$ of mean lost earnings for males with limitations.

${ }^{33}$ It should be noted, however, that all estimates of the work-related losses attributable to disability/health limitations, excluding Chirikos and Nestel (1985), rest on a static model of the determinants of potential earnings capability. In such models, the early presence of a disability/health limitation is not permitted to affect the values of background characteristics such as education that determine estimated potential earnings capability (PEC). Should early disability/health limitations reduce educational attainment below what it would be in the absence of the limitation, our estimate of LEC would be biased downward. Nor do these models include the effect of prior poor health on wages of those who currently are in good or excellent health. Only individual longitudinal data extending over several years could correct this problem.

${ }^{34}$ The $\lambda$ variable is not used in predicting earnings because we want the unconditional predicted value of eamings. That is, we want the predicted earnings to be the same for people with the same demographic characteristics whether or not we observe them working.

${ }^{35}$ We also control for involuntary part-time employment. If a person reported they worked part-time because of the inability to find fulltime employment, their predicted earnings are multiplied by .5 , implying that this exogenous factor constrains work capability to twenty hours per week. 
${ }^{36}$ We thank Thomas Buchmueller (University of California, Irvine) for making this data set available to us. 


\section{References}

Chirikos, T. N. 1989. "Aggregate Economic Losses from Disability in the United States: A Preliminary Assay." The Milbank Quarterly, 67, suppl. 2, Pt. 1: 59-91.

Chirikos, T. N., and G. Nestel. 1985. "Further Evidence on the Economic Effects of Poor Health."

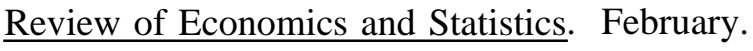

Cooper, B. S., and D. P. Rice. 1976. "The Economic Cost of Illness Revisited." Social Security Bulletin, 39(2): 21-36.

Hartunian, Nelson, Charles Smart, and Mark Thompson. 1981. The Incidence and Economic Costs of Major Health Impairments. Lexington, Mass: Lexington Books.

Haveman, Robert H., and Lawrence Buron. Forthcoming. "Who Are the Truly Poor? Patterns of Official and Net Earnings Capacity Poverty, 1973-1988." In Poverty and Prosperity in America at the Close of the Twentieth Century, ed. Dimitri Papadimitriou and Edward Wolff. London: Macmillan Press.

Haveman, Robert H., Victor Halberstadt, and Richard V. Burkhauser. 1984. Public Policy toward Disabled Workers: Cross-National Analyses of Economic Impacts. Ithaca: Cornell University Press.

Haveman, Robert H. and Barbara L. Wolfe. 1984. "Disability Transfers and Early Retirement: A Causal Relationship." Journal of Public Economics, 24: 42-66.

Hensler, Deborah, et al. 1991. Compensation for Accidental Injuries in the United States. Santa Monica, Calif.: Rand Corporation.

Maddala, G. S. 1983. Limited Dependent Variables in Econometrics. Cambridge: Cambridge University Press.

Manning, Willard, E. B. Kecler, Joseph P. Newhouse, et al. 1989. "The Taxes of Sin: Do Smokers and Drinkers Pay their Way?" Journal of the American Medical Association, 261: 1604-09. 
Parsons, Donald O. 1980. "The Decline in Male Labor Force Participation." Journal of Political Economy, 88(February): 117-34.

Rice, Dorothy, T. A. Hodgson, and A. N. Kopstein. 1985. "The Economic Costs of Illness: A Replication and Update." Health Care Financing Review, 6(1): 61-80.

Rice, D., S. Kelman, and L. Miller. 1991. "Estimates of Economic Costs of Alcohol and Drug Abuse and Mental Illness, 1985 and 1988." Public Health Reports, 106(3): 280-92.

U.S. Department of Commerce, Bureau of the Census. 1989. "Labor Force Status and Other Characteristics of Persons with Work Disabilities, 1981 to 1988." Current Population Reports, Special Series No. 160, p. 23.

Wolfe, Barbara. 1984. "Editorial: Measuring Disability and Health." Journal of Health Economics, 3: 187-93.

Wolfe, Barbara and Robert Haveman. 1990. "Trends in the Prevalence of Disability, 1962-1984." The Milbank Quarterly, 68(1): 53-80.

Wolfe, Barbara and Steven C. Hill. Forthcoming. "The Health, Earnings Capacity, and Poverty of Single-Mother Families." In Poverty and Prosperity in America at the Close of the Twentieth Century, ed. Dimitri Papadimitriou and Edward Wolff. London: Macmillan Press. 